\title{
Od godności dobrze urodzonych po egalitarne szlachectwo dla wszystkich. Szkice ze studiów nad ideą godności człowieka
}

Zasada godności człowieka jest jednym z najważniejszych elementów systemu prawa. Jeden $\mathrm{z}$ amerykańskich teoretyków prawa drugą połowę XX w. nazwał wręcz era godności $i^{1}$ Temu wzrostowi znaczenia godności $\mathrm{w}$ teorii i praktyce prawa towarzyszą zażarte dyskusje. Spory toczą się na wielu płaszczyznach, począwszy od tego, czym w istocie jest godność oraz jak ją zdefiniować (i czy jest to w ogóle możliwe), poprzez wskazanie jej początków i genezy, opisania ewolucji pojmowania tej idei, a skończywszy na funkcjach, jakie pełni, i roli, jaką odgrywa, lub powinna odgrywać, godność w systemie prawnym państw demokratycznych.

Dyskusja nie ogranicza się jedynie do pola nauki prawa i stosowania prawa, gdzie godność jest przede wszystkim związana z dyskursem o prawach człowieka. Debaty o godności oraz polemiki, w których pojawia się ta idea jako argument, toczą się dziś na wielu polach. Jednym z najpoważniejszych jest bioetyka, gdzie idea godności omawiana jest w kontekście wielu zawiłych problemów, które mają coraz większy wpływ na nasze życie. Wystarczy wymienić takie zagadnienia, jak aborcja, zapłodnienie in vitro, klonowanie, inżynieria genetyczna, badania nad komórkami macierzystymi czy eutanazja, by zrozumieć, w jak wielu kontekstach jest dziś używany termin godność. Nie trzeba zresztą wychodzić poza sferę nauki prawa, by uzmysłowić sobie, jak często idea godności jest przywoływana. Szeroko pojęta sfera praw człowieka, czyli prawo międzynarodowe, to takie problemy, jak tortury i prześladowania, walka z głodem i ubóstwem, pomoc humanitarna i problem uchodź-

${ }^{1}$ J.Q. Whitman, On Nazi Honor and New European Dignity, [w:] Darker Legacies of Law in Europe. The Shadow of National Socialism and Fascism over Europe and its Legal Traditions, red. C. Joerges, N.S. Ghaleigh, Oxford 2003, s. 243, cytat za: S. Hennette-Vauchez, A human dignitas? Remnants of the ancient legal concept in contemporary dignity jurisprudence, ,International Journal of Constitutional Law” 2011, t. 9, nr 1, s. 34. 
ców oraz cywilnych ofiar toczących się wojen. Z kolei prawo konstytucyjne to problemy dyskryminacji (np. kobiet w części krajów rozwijających się), wieloaspektowe zagadnienie praw socjalnych, ekonomicznych i kulturalnych czy problem praw zwierząt, w którym godność także ogrywa znaczącą rolę. Niestety wymienione wyżej problemy nie wyczerpują listy kontekstów, w których pojawia się termin godność.

Wszystko to sprawia, że godność jest ideą wielowymiarową. $\mathrm{Z}$ jednej strony liczne dyskusje ugruntowują pozycję tej idei i mogą ułatwić zrozumienie jej istoty. Z drugiej jednak - taka sytuacja właściwie uniemożliwia, a przynajmniej niesamowicie utrudnia całościowe opisanie czegoś, co można by nazwać doktryną godności, gdyż wykracza ona daleko poza sferę filozofii, teorii i praktyki prawa, śmiało wkraczając na pola etyki, moralności, bioetyki, medycyny, globalnej polityki, a nawet religii. Jak wielki problem stoi przed badaczami idei godności, uświadamia sam fakt zróżnicowania języków, jakimi posługują się specjaliści w każdej z wyżej wymienionych dziedzin. Pojęcia i terminy z różnych dziedzin nie zawsze odpowiednio do siebie przystają, a co za tym idzie ciężko znaleźć język, który nie tyle zadowoli terminologiczny zmysł, ile pozwoli w sposób spójny opisać godność w tak wielu różnych aspektach. Być może dlatego dyskusje i debaty o godności są tak trudne, ponieważ uczestniczą $\mathrm{w}$ nich specjaliści z różnych dziedzin, którzy posługują się terminami, zupełnie inaczej je rozumiejąc.

Wydawać by się mogło, że idea godności jest już na tyle ukształtowana w filozofii, etyce i kulturze, iż w systemie prawa funkcjonować będzie jako klarowna, jasna i niesporna instytucja czy zasada prawa. Że jej interpretacja, realizacja jej treści w praktyce i wpływ na stosowanie prawa będą jednoznaczne. Że raczej będzie wyjaśniać spory, aniżeli je zaogniać. Niestety coraz liczniejsze debaty nad godnością nie kończą się, a wręcz stają się coraz bardziej intensywne. Co więcej, idea godności albo godność jako zasada prawna (instytucja) stała się wygodnym argumentem dla wielu - często przeciwstawnych - stron sporów. Pewna wieloznaczność i niedookreśloność terminu godność, która powinna być zaletą, stała się w oczach wielu myślicieli, bioetyków, filozofów czy publicystów wręcz wadą. Użycie argumentu odnoszącego się do godności stało się bardzo wygodne, co spowodowało krytykę istoty godności i głosy o jej nieprzydatności jako idei czy instytucji ${ }^{2}$. Niektórzy podejrzewają, że idea godności to zakamuflowany argument zwolenników prawa naturalnego, część wskazuje, że godność stała się argumentem zbyt mocno odwołującym się do sfery religijności, a przez to stała się bardziej anachroniczna. Część specjalistów wskazuje, że godność jest pustym frazesem, zwrotem, który nic nie znaczy albo jest zbiorem nieokreślonych życzeń

2 Jako bezużyteczną koncepcję, ideę godności określiła w swym artykule Ruth Macklin, pisząc, iż ,godność to nic więcej jako szacunek dla osób i ich autonomii” [w:] R. Macklin, Dignity is a useless concept, „British Medical Journal” nr 327 (7429), 20-27.12.2003, s. 1419. 
co do tego, jak powinno się ten termin rozumieć ${ }^{3}$. Ważnym zarzutem jest stwierdzenie, że godność nie wnosi nic nowego lub znaczącego do globalnej debaty nad prawem. Dla idei czy zasady prawnej to zarzut wręcz śmiertelny, bo godzący w samą istotę prawa - jego funkcjonalność i celowość.

Nie mniej gorące spory toczą się wokół genezy godności w filozofii i prawie. Teoretycy i filozofowie prawa spierają się, czy współcześnie pojmowana godność ma swe korzenie w starożytnej filozofii greckiej, instytucjach prawnych starożytnego Rzymu, początkach chrześcijaństwa czy włoskim odrodzeniu. Część wskazuje, iż jej źródeł należy szukać w dużo bliższych nam osiągnięciach rewolucji z końca XVIII w. lub tragicznych doświadczeniach $\mathrm{XX}$-wiecznych wojen i ludobójczych totalitaryzmów. Oczywiście należy zadać pytanie, czy można znaleźć jedno źródło, czy też należy mówić o wielu, które w drodze ewolucji pojmowania i stosowania dały efekt w postaci dzisiejszej idei? Zresztą sama ewolucja i historia idei godności także jest przedmiotem sporów. Które z wielu rozumień godności można zaliczyć do prawnych przodków godności nam współczesnej, a które łączy z nią tylko nazwa? Czy dostojeństwo duchownych albo rycerska cześć mogą być uważane za prawowitych antenatów równej i przyrodzonej godności każdego człowieka? Czy też może są jej kompletnym przeciwieństwem, którego należy się wystrzegać w dzisiejszym egalitarnym świecie?

A to dopiero początek sportów i wątpliwości związanych z ideą godności. Do rozważenia pozostaje bowiem rola i funkcje godności jako instytucji prawnej. Zaczynając od dyskursu praw człowieka, rodzi się pytanie, czy godność jest fundamentem praw i wolności człowieka? Jeżeli tak, to dlaczego pierwsze deklaracje: amerykański Bill of Rights i francuska Deklaracja praw człowieka i obywatela nie odwołują się do godności jako swego źródła? Co więcej, w żadnym w tych tekstów godność nie pojawia się w żadnej innej roli (z wyjątkiem art. VI francuskiej Deklaracji, gdzie mowa jest o godności - lub dostojeństwach $-\mathrm{w}$ znaczeniu zaszczytnych stanowisk publicznych). Czy zatem słusznie w XX w. właściwie wszystkie akty praw człowieka, począwszy od Powszechnej Deklaracji Praw Człowieka z 1948 r. jako źródło praw uznają godność? Być może zatem idea godności jako źródła praw człowieka nie ma tak wspaniałego drzewa genealogicznego, jak się powszechnie sądzi, a jest jedynie ideą na wskroś współczesną, która do fundamentów praw człowieka została dodana, jako zasada uzupełniająca katalog źródeł, po doświadczeniach totalitarnych zbrodni ludobójstwa,.

Warto także sięgnąć do orzecznictwa amerykańskiego Sądu Najwyższego, w którym godność w pewnym momencie zaczęła pełnić niezwykle istotną rolę. Można pokusić się o hipotezę, iż idea godności do amerykańskiego

\footnotetext{
${ }^{3}$ Niezwykle krytycznie o idei godności wypowiadał się np. Steven Pinker, m.in. w swym artykule wymownie zatytułowanym The Stupidity of Dignity, [w:] S. Pinker, The Stupidity of Dignity, „The New Republic” 28.05.2008.
} 
prawa trafiła w drodze doktryny sędziowskiej, a nie poprzez prawo pisane. Jest to ciekawy element doktryny godności, który wymaga dalszych badań. Dziś powszechnie w amerykańskiej nauce prawa uważa się, że godność odgrywa jedną $\mathrm{z}$ pierwszoplanowych ról $\mathrm{w}$ systemie konstytucyjnych praw i wolności ${ }^{4}$.

Kolejnym zagadnieniem jest to, czy godność pełni wyłącznie rolę fundamentu, czy też o godności można mówić jako o określonym indywidualnym prawie, tj. prawie do godności. Coraz częściej w teorii i filozofii prawa można spotkać tezy o istnieniu prawa do godności ${ }^{5}$. Co zatem oznacza owo „prawo do godności" i czy możemy mówić o jednym prawie, czy też o zespole praw godnościowych, tak jak to robi np. europejska Karta Praw Podstawowych? Następnym zagadnieniem związanym z ideą godności i jej miejscem w dyskursie nad prawami człowieka jest jej stosunek do praw socjalnych, ekonomicznych i kulturalnych. Wreszcie jednym z najnowszych kierunków badań jest odpowiedź na pytanie, czy godność przysługuje wyłącznie jednostkom, czy też może przysługiwać grupom lub całym narodom?

Wobec ogromu zagadnień związanych z ideą godności, zadanie niniejszego artykułu jest zdecydowanie skromniejsze i polega na przedstawieniu kilku wyjątków z ponaddwuwiekowej najnowszej historii doktryny godności. W tym celu omówione będą wyjątki z dwóch wielkich debat, które dzieli prawie 200 lat. W pierwszej kolejności przedstawione zostaną poglądy ojca konserwatyzmu, Edmunda Burke'a, które zawarł w swych Rozważaniach o rewolucji we Francji. Jego poglądy to przykład stanowiska zachowawczego w obliczu rewolucji i narodzin idei praw człowieka. Jako głos opozycyjny do zastanej rzeczywistości (i polemiczny w stosunku do opinii Burke'a) przedstawione będą opinie i poglądy Mary Wollstonecraft, jednej z prekursorek sufrażystek, filozofii feministycznej i anglosaskiego liberalizmu. Następnie omówione będą poglądy Gregory’ego Vlastosa, który w latach 80. XX w. opracował oryginalną koncepcję godności jako idei egalitarnej o elitarnej treści. Koncepcja ta rozwijana jest przez anglosaskiego filozofa i teoretyka prawa Jeremy'ego Waldrona. Na koniec przedstawione będą krytyczne wobec tej koncepcji uwagi francuskiej profesor Stéphanie Hennette-Vauchez.

Burke i tradycjonalistyczne ujęcie idei godności. Wspomniane dzieło Edmunda Burke'a uważane jest za fundament myśli konserwatywnej. Burke opisywał rewolucyjne wydarzenia we Francji. Chciał jednak, by stanowily

${ }^{4}$ The Constitution of Rights. Human Dignity and American Values, red. M.J. Meyer, W.A. Parent, Ithaca - Londyn 1992, s. 1.

${ }^{5}$ Tak m.in. Rex D. Glensy, The Right to Dignity, „Columbia Human Rights Law Review”, t. 43 2011-2012; Alfonsas Vaišvila. Human Dignity and the Right to Dignity in Terms of Legal Personalism. (From Conception of Static Dignity to Conception of Dynamic Dignity), „Jurisprudencija" 2009, nr 3(117). 
one jedynie przykład dla angielskiego czytelnika i pisał o swoim kraju, a raczej o zagrożeniach dla niego, jakie widział i których się obawiał. Jego dzieło wywołało wielki odzew i liczne polemiki, w których pojawiło się odmienne od tradycyjnego pojmowanie idei godności (m.in. Prawa czlowieka Tomasza Paine'a czy Wołanie o prawa czlowieka Mary Wollstonecraft). Dlatego zasadne wydaje się chociażby krótkie przedstawienie wyjątków z myśli Burke'a, które dotyczą idei godności.

Burke bronił istniejącego ustroju politycznego i społecznego jako właściwego ze względu na tradycję, która z kolei była według niego zgodna z ludzką naturą. Fakt wielowiekowego istnienia pewnych instytucji i relacji społecznych skutkował w jego oczach pozytywną oceną. Państwo oraz jego instytucje miały określony kształt, ukształtowany przez wielowiekową tradycję, ponieważ wypływało to z ludzkiej natury i było z nią zgodne. Wszelkie tradycyjne zwyczaje i zasady społeczne były tego wyrazem, także tradycyjne godności wysoko urodzonych. Wierność tradycji była wyrażana „, budowlach, w muzyce, $\mathrm{w}$ dekoracjach, $\mathrm{w}$ mowie, $\mathrm{w}$ znamienitości osób [w oryginale: dignity of persons - przyp. aut.], zgodnie z obyczajami, jakich nauczyła ich natura"6.

Zasadniczo godność szła w parze z urzędami, urodzeniem i bogactwem. Jak stwierdził Burke, „godność każdego zajęcia mierzy się natężeniem i rodzajem cnoty, jaką można w nim okazać" "P. Pisząc o urzędzie ministra, Burke zaznaczał, iż należy do „najbardziej godnych”8. Bez wątpienia godność przysługuje królowi, co dla Burke'a jest niepodważalne (zaś królowej w każdej sytuacji przystoi zachowanie się z „godnością rzymskiej matrony"9). Władzę monarszą powinna cechować „godność, autorytet i poważanie”" Nawet kara dla tyrańskiego monarchy musi być odpowiednia do jego majestatu ${ }^{11}$. Burke, pisząc krytycznie o francuskich reformach władzy królewskiej, wskazywał, iż „godności tego nieszczęśliwego władcy o wiele lepiej służyłaby sytuacja, w której nie miałby w ogóle nic wspólnego z wymiarem sprawiedliwości, skoro wyzuto go z wszystkiego, co w tej funkcji czcigodne i pojednawcze" 12 .

Także dlatego Burke bronił majątku Kościoła przed konfiskatą - ubodzy duchowni nie będą mieli w oczach swych wiernych szacunku. Byłoby inaczej jedynie gdyby ubóstwo było świadomym wyborem. Ci, którzy świadomie po-

${ }^{6}$ E. Burke, Rozważania o rewolucji we Francji, Warszawa 2008, s. 175.

${ }^{7}$ Ibidem, s. 308.

${ }^{8}$ Ibidem, s. 283, w oryginale: In all other countries, the office of ministers of state is of the highest dignity. Wszystkie cytaty w języku angielskim pochodzą $\mathrm{z}$ tekstu dostępnego na stronach Archiwum Historii Myśli Ekonomicznej kanadyjskiego Uniwersytetu MacMaster w Ontario (dostęp 01.06.2014) http://socserv2.mcmaster.ca/ econ/ugcm/3113/burke/revfrance.pdf

${ }^{9}$ E. Burke, Rozważania..., op. cit., s. 152.

${ }^{10}$ Ibidem, s. 280.

${ }^{11}$ Ale gdybym miat ukarać niegodziwego króla, starałbym się pomścić zbrodnię w sposób godny. Ibidem, s. 160. W oryginale: I should regard the dignity in avenging the crime.

${ }^{12}$ E. Burke, Rozważania ..., op. cit., s. 280. 
zbywają się swego majątku oraz wszelkich ludzkich potrzeb mogą zyskać nie tylko szacunek w oczach innych. Według Burke'a „człowiek, który nie ma żadnych potrzeb, zyskuje wielką wolność, moc, a nawet godność"13. Podobnie wyniesienie do godności może nastąpić, jeśli działa się w imię Boże ${ }^{14}$.

Godność pojawia się też w kontekście obrony majątków kościelnych, gdy Burke pisze o duchowieństwie, które dzięki posiadanemu majątkowi może być dla osób spoza stanu szlacheckiego szansą na zdobycie „,godności i dostojeństwa" 15 .

Burke używał pojęcia godności w odniesieniu do osób, które wykonują zawód lub piastują urząd, który cieszy się powszechnym uznaniem i szacunkiem. Skutkuje to wyrobieniem w sobie pewnego poczucia godności, co Burke oceniał pozytywnie. Natomiast innym takiego poczucia stanowczo odmawiał. Krytycznie pisał zwłaszcza o deputowanych zasiadających w rewolucyjnym parlamencie. Nie szczędził im gorzkich słów sarkazmu, retorycznie pytając, czy trzeba się „lękać przesławnego autorytetu i imponującej godności garstki zasiadających w Zgromadzeniu wioskowych gburów"16. Ubolewając natomiast nad wykształceniem nowych deputowanych (wśród których przewagę zdobyli kupcy, medycy i prawnicy), pisał, iż nie są oni przyzwyczajeni do ,poczucia godności”'17.

Burke, krytykując francuskie idee wyłaniania członków parlamentu, podkreślał, iż są niekorzystne dla arystokracji i nie służą one ochronie ich majątków. Powinno tak być, gdyż jak uważał, „w ustroju republikańskim, opartym na demokratycznej zasadzie, bogactwo powinno być chronione bardziej, niż jest to konieczne w przypadku monarchii”. Bogaci są bowiem „przedmiotem zawiści, a za jej sprawą - gnębienia”. Wskutek tego „człowiek bogaty nie może jej [reprezentacji i jej reguł - przyp. aut.] uznać ani za wspierającą jego godność, ani chroniącą jego fortunę"18.

Wykonywanie nawet najpośledniejszych zawodów łączy się z pewnym poczuciem godności. Burke, sarkastycznie pisząc o stosunku władz rewolucyjnych do monarchy, stwierdzał, iż tak zjadliwy wobec swych ofiar nie jest nawet „kat Paryża, który dzięki Zgromadzeniu Narodowemu został uszlachcony i otrzymał stosowną rangę i herb w Heraldycznym Kolegium Praw Czło-

13 Ibidem, s. 180.

${ }^{14}$ Czy nadwyżka oliwy $i$ wina spożytkowana jest gorzej, gdy zaspokaja skromne potrzeby osób, które za sprawa wizji pobożnej wyobraźni, budowanie w imię Boże wynosi do godności, niż gdy przeznaczana jest na przekarmianie nieprzeliczonej rzeszy ludzi poniżonych poprzez to, że uczyniono ich nieużytecznymi sługami człowieczej pychy? Ibidem, s. 241.

15 (...) własności, która za sprawa swego przeznaczenia, ale także i zasług poszczególnych osób stanowi dla najszlachetniej urodzonych rodzin źródło odrodzenia i wsparcia, a dla ludzi najniższego stanu drogę do godności i dostojeństwa. Ibidem, s. 242

${ }^{16}$ Ibidem, s. 118.

${ }^{17}$ Ibidem.

${ }^{18}$ Ibidem, s. 256. 
wieka, jest mężem zbyt wspaniałomyślnym, zbyt rycerskim, zbyt przepełnionym poczuciem własnej nowej godności”"

Poczucie godności z tytułu wykonywanego zawodu, piastowanego urzędu lub funkcji było dla Burke'a istotnym uczuciem, które miało szereg pozytywnych funkcji. Poczucie dumy z racji zajmowanego miejsca i więzi z innymi członkami tej samej kasty jest początkiem uczuć w sferze publicznej: umiłowania ojczyzny oraz całej ludzkości ${ }^{20}$. Dowodem upadku tych, którzy - mimo urodzenia lub zawodu - są zwolennikami rewolucji, jest „,całkowite lekceważenie godności, którą dzielą z innymi” ${ }^{21}$. Jest to wyraz ich „egoistycznej i chorej ambicji”, a skutkiem jest niepamięć o ich obowiązku dbałości o swoją grupę ${ }^{22}$. Skutkiem tego jest upadek: „gdy ludzie wysokiej rangi poświęcają wszelkie wyobrażenia o godności dla pozbawionej wyraźnego celu ambicji i dążą do niegodnych celów za pomocą niegodnych środków, cały system staje się niegodny i podły"23.

Tradycyjne instytucje społeczne i polityczne są ważnym elementem ustrojowym, dzięki którym właściwie może funkcjonować państwo o właściwym ustroju, który będzie pomiędzy absolutną monarchią a rewolucyjnymi rządami ludu, które Burke krytykował. Ważną rolę - ograniczającą absolutną władzę króla odgrywają w takim ustroju „odziedziczone majątki i dziedziczne godności”, będące w rękach elity narodu. Burke retorycznie pytał, „czy w całej masie teorii i praktyk gentlemeni ci nie spotkali się z niczym, co leżałoby między despotyzmem monarchy a despotyzmem pospólstwa? Czy nie słyszeli nigdy o władzy królewskiej kierowanej przez prawa, kontrolowanej i równoważonej przez wielkie odziedziczone majątki i dziedziczne godności, które to z kolei władze poddawane są sprawiedliwemu osądowi wypływającemu z rozumu i uczuć całego narodu, reprezentowanego przez stosowny i stały organ" ${ }^{24}$.

Godność u Burke'a pojawia się także w odniesieniu do całego narodu. Burke chwalił instytucje angielskie między innymi dlatego, iż są one zgodne $\mathrm{z}$ naturą, zaś liczne odwołania do niej wzmacniają niepewne rozwiązania wytworzone przez ludzki rozum (który jest władzą słabą i omylną). Dzięki temu Anglicy jako jedni z nielicznych odziedziczyli liczne swobody, które Burke nazywa „duchem wolności”. Jest to jednak efekt ciągłego zwracania uwagi na tradycję, działania ,jakby w obecności naszych świętych przodków. To szla-

\footnotetext{
${ }^{19}$ Ibidem, s. 146.

${ }^{20}$ Przywiąanie do grupy, umiłowanie tego małego oddzialu, do którego należymy w społeczeństwie, stanowi pierwsza zasadę, (zarodek jakby) publicznych uczuć. Ona to tworzy pierwsze ogniwo łańcucha prowadzacego nas ku miłości ojczyzny i rodzaju ludzkiego. Ibidem, s. 121.

${ }^{21}$ Ibidem.

${ }^{22}$ Interesy tej cząstki społecznego ustroju stanowia dobro powierzone pieczy wszystkich, którzy się na nia składaja, i podobnie jak tylko zty czlowiek usprawiedliwiałby jego nadużycie, tylko zdrajca kupczyłby nim dla osobistych korzyści. Ibidem.

${ }^{23}$ Ibidem, s. 122.

${ }^{24}$ Ibidem, s. 201.
} 
chetne dziedzictwo budzi w nas poczucie tradycyjnej narodowej godności, która chroni nas przed parweniuszowską butą"25. Burke uważał, iż Francuzi też mogliby czuć taką dumę ze swej przeszłości. Gdyby pochopnie nie odrzucili dotychczasowych rozwiązań ustrojowych, mogliby „nadać swojej odzyskanej wolności taką samą godność" 26 .

Tak jak godność posiada naród, tak samo godność posiada całe państwo. Burke uważał, iż właśnie ,godności i znaczeniu państwa” zagraża rewolu$\mathrm{cja}^{27}$. W dodatku francuską rewolucję prowadzą ludzie, którzy nie mają ku temu zdolności politycznych ani odpowiednich horyzontów myślowych. „Inne rewolucje były kierowane przez osoby, które projektując lub przeprowadzając zmiany w państwie, uświęcały swe ambicje utwierdzając godność ludzi, których spokój zakłócały"28. Właśnie dlatego Francja, mimo rozlicznych tragicznych wydarzeń w przeszłości, nie straciła „ducha kraju”. Wśród wartości, które się na niego składają, Burke obok poczucia własnej godności wymienił szlachetną dumę, wielkoduszną chwałę i współzawodnictwo ${ }^{29}$.

Burke odwoływał się do poczucia godności, krytykując demokrację. Uważał, iż rządy ludu oznaczają brak odpowiedzialności za działania i ich skutki lub nadużycia. Nikt nie dopuszcza myśli, iż za złe decyzje podjęte wspólnie może być ukaranym, bo - jak konstatował Burke - ogół społeczeństwa bez wątpienia nie może zostać ukarany. Ludzie nie mogą dopuścić do siebie myśli, że ich wola może decydować o tym, co jest dobre, a co złe. U wszystkich, którzy taką wolę ludu będą wykonywać doprowadzi to do zaniku ,wszelkich zasad moralnych, poczucia godności, niezależności sądu i wszelkiej spójności charakteru" 30 .

Są pewne fragmenty dzieła Burke'a, w których znaleźć można odniesienia do godności człowieka. To użycie terminu godność jest jednak charakterystyczne dla społeczeństwa feudalnego, w którym godność przysługuje tylko nielicznym, zaś pozostali mogą osiągnąc tę wartość jedynie w określonych warunkach. Jednak nawet $\mathrm{w}$ takich sytuacjach, godność pojawia się niejako obok, jako pochodna określonych sytuacji lub stanów społecznych.

Broniąc tradycji i zwyczajów, Burke argumentował, iż są one niezbędne dla nadania życiu pewnej ogłady i przyzwoitości. Są konieczne ze względu na ułomność natury ludzkiej, która potrzebuje pewnych reguł i zasad, by móc zbudować właściwie funkcjonującą wspólnotę. Obyczaje i zwyczaje tworzą

${ }^{25}$ Ibidem, s. 109.

${ }^{26}$ Ibidem.

${ }^{27}$ Czyż nie powoluje ona do życia czegoś niegodziwego i haniebnego: swoistej nikczemności większości działań politycznych, obecnej we wszystkich poczynaniach skłonności do poniżania nie tylko jednostek, lecz także godności i znaczenia państwa? Ibidem.

${ }^{28}$ Ibidem, s. 122.

${ }^{29}$ Ibidem, s. 123.

${ }^{30}$ Ibidem, s. 171 . 
niezbędne dla życia ,iluzje, które czyniły władzę łaskawą, a posłuszeństwo szlachetne"31. To dzięki pewnym konwencjom społecznym możliwe jest pokrycie „defektów naszej nagiej, ułomnej duszy i nadania jej godności w naszych oczach" ${ }^{\prime 32}$. Wszystko to ma zostać zastąpione przez ,imperium światła i rozumu"33. W podobnym kontekście obrony przeszłości (zwyczajów z przeszłości) godność pojawiła się, gdy Burke pisał o należytym traktowaniu pokonanego francuskiego monarchy (odwoływał się tu do historii Jana II Dobrego), wskazując, iż Anglicy nie pozbyli się „,wielkoduszności i godności właściwych duchowi XIV wieku"34.

W innym miejscu Burke pisał o znaczeniu zwyczajów i obyczajów dla zwykłych ludzi. Ważną rolę widział we wszystkich uroczystych publicznych aktach, które stanowią „ozdobę życia społecznego” oraz „napawają społeczeństwo otuchą" ${ }^{35}$. To dzięki ich istnieniu, niejako w nich samych ludzie najniższych stanów mogą odnaleźć swe „znaczenie i godność” ${ }^{36}$.

Ten pozytywny stosunek do przeszłości przekładał się u Burke'a także na stosunek do ludzi starszych, mogących poszczycić się doświadczeniem, zwłaszcza politycznym. O wieku dojrzałym Burke pisał bowiem jako o „nieugiętej i stanowczej godności wieku podeszłego"37.

Mary Wollstonecraft i nowożytne pojmowanie idei godności. Godność u Burke'a pojawiała się jako tradycyjna cecha przynależna z racji urodzenia lub pełnionych urzędów. Oprócz tego pojawia się w innych kontekstach, które nie są ze sobą powiązane. Nie ma więc mowy o używaniu terminu godność w sposób nowożytny - jako pewnej wartości przynależnej jednostce wyłącznie z racji samego człowieczeństwa. Natomiast takie ujęcie pojawi się już w tekstach jego oponentki, Mary Wollstonecraft ${ }^{38}$. Rozkwit jej twórczości przypadł na burzliwe czasy wielkiej rewolucji. Zresztą sama autorka pewien czas przebywała w tym okresie we Francji. Jej pierwsze wielkie dzieło, Wołanie o prawa czlowieka, to polemika właśnie z Rozważaniami o rewolucji we Francji Edmunda Burke'a. Dzieło powstało w 1790 r. i przyniosło autorce

${ }^{31}$ Ibidem, s. 153.

${ }^{32} \mathrm{~W}$ oryginale Burke nie wspominał o duszy, lecz o naturze ludzkiej: All the super-added ideas, furnished from the wardrobe of a moral imagination, which the heart owns and the understanding ratifies as necessary to cover the defects of our naked, shivering nature, and to raise it to dignity in our own estimation, are to be exploded as a ridiculous, absurd, and antiquated fashion (patrz przyp. 5).

${ }^{33}$ E. Burke, Rozważania ..., op. cit., s. 154.

${ }^{34}$ Ibidem, s. 163.

35 Ibidem, s. 175.

${ }^{36}$ Ibidem, s. 176.

${ }^{37}$ Ibidem, s. 297.

${ }^{38}$ Mary Wollstonecraft (1759-1797) - angielska prekursorka ruchu sufrażystek oraz feminizmu i liberalizmu. 
spory rozgłos. Drugi, znacznie obszerniejszy utwór pt. Wołanie o prawa kobiet (w wielu miejscach dzieło polemizujące z Emilem Jana Jakuba Rousseau) powstał w 1792 r. W Polsce jej twórczość jest szerzej nieznana (dopiero w 2011 r. przetłumaczono na język polski jej najważniejsze dzieła ${ }^{39}$ ). Natomiast w krajach anglosaskich dzięki swej twórczości zajmuje poczesne miejsce wśród myślicieli i filozofów (świadczy o tym chociażby fakt, iż jej dzieła znaleźć można w prestiżowym zbiorze Projektu Gutenberg ${ }^{40}$ ).

Czytając dzieła angielskiej autorki, nie sposób oprzeć się wrażeniu, że jej system wartości jest na wskroś nowoczesny i że w niektórych kwestiach (nie chodzi tu bynajmniej wyłącznie o dyskryminację kobiet) wręcz wyprzedza swoją epokę. Podobnie sposób, w jaki argumentuje za swymi racjami jest bliski XX-wiecznemu postrzeganiu świata. Widać to zwłaszcza w polemice z Burke'em, kiedy to jego odwołaniom do tradycji Wollstonecraft przeciwstawiała argumenty czysto racjonalne i logiczne.

Wollstonecraft walczyła z biedą i ubóstwem, widząc w nich fundamenty niedorozwoju cywilizacji. Przeciwna była także nierównościom społecznym (choć krytyka własności jest słabszą stroną jej postulatów, a pomysły w tej kwestii wydają się utopijne). $Z$ pełnym oddaniem i zaangażowaniem krytykowała niewolnictwo i dyskryminację kobiet. Za podstawowe narzędzie zmiany uważała zaś edukację. Takie ujęcie problemów wydaje się żywcem wyjęte z agendy działań licznych organizacji międzynarodowych czy ponadnarodowych 2. połowy XX w.

Co najważniejsze dla tematu artykułu, w pracach Wollstonecraft w wielu miejscach pojawiła się godność człowieka w kilku ujęciach. Jedne uznać należy za jasno sprecyzowane, prekursorsko stosowane, w innych miejscach godność jawi się bardziej mgliście i jej rolę trzeba wyinterpretować z kontekstu. Po pierwsze, Wollstonecraft za jeden z celów rozprawy Wołanie o prawa kobiety uznała opisanie, ,na czym polega prawdziwa godność i ludzkie szczęście"41. Po drugie, godność rozumiana jako przyrodzona każdemu człowiekowi wartość (tu Wollstonecraft jawi się jako prekursor XX-wiecznego postrzegania praw człowieka). Po trzecie, jako istotna cecha naszych zdolności naturalnych, które odróżniają człowieka od zwierząt i stanowią o jego wyjątkowości (w tym znaczeniu Wollstonecraft pisze o godności rozumu, godności charakteru). Wreszcie idea godności pojawiła się w myśli Wollstonecraft jako pewien ostateczny cel istnienia jednostki, do którego człowiek powinien dążyć w swym życiu.

\footnotetext{
${ }^{39}$ Warto podkreślić, iż od 1 stycznia 2014 r. thumaczenie na język polski należy do domeny publicznej.

${ }^{40}$ Wszystkie przypisy w oryginale pochodzą z tekstu zamieszczonego na stronie http://www. gutenberg.org/ebooks $/ 3420$

${ }^{41}$ M. Wollstonecraft, Wolanie o prawa kobiety, [w:] M. Wollstonecraft, Wolanie o prawa kobiety, Warszawa 2011, s. 44.
} 
Podstawowym celem Wolania o prawa kobiety była walka o prawo kobiet do traktowania ich na równi z mężczyznami. Sytuację, w której połowa ludzkości wyłączona jest $\mathrm{z}$ możliwości korzystania $\mathrm{z}$ uprawnień wynikających $\mathrm{z}$ praw naturalnych zadeklarowanych $\mathrm{w}$ rewolucyjnych aktach prawnych, Wollstonecraft uznawała za niesprawiedliwą, a co ważniejsze - za zupełnie nieracjonalną i nielogiczną. Odwoływała się tu do opinii Talleyranda o francuskiej konstytucji z $1791 \mathrm{r}^{42}$ Uznając niezależność za „najświętsze błogosławieństwo życia i fundament całej cnoty"43, Wollstonecraft zauważała, że kobieta niesamodzielna, zależna od mężczyzny, „zatrzyma postęp wiedzy”44. Tylko bowiem jednostka wolna może właściwie korzystać ze swych zdolności, w tym z rozumu, by świadomie kształtować swoje życie, rozwijając się i dążąc do wyższych celów (cnoty, szczęścia, godności). Wollstonecraft pisała, iż „dopóki wolność nie wzmocni jej rozumu, nie pojmie ona własnych powinności i nie zobaczy, jaki związek mają z jej prawdziwym dobrem" ${ }^{45}$. Aby jednak w pełni móc korzystać ze swych naturalnym możliwości, konieczne jest ich właściwe ukształtowanie. Tu zaś podstawą jest edukacja i nauka, jak bowiem przyznawała prekursorka feminizmu, ,zaniedbania w edukacji moich bliźnich są największym źródłem nędzy"46.

W prosty sposób Wollstonecraft udowadniała nieracjonalność nierówności płci, pisząc, iż „nawet jeśli kobiety to istoty z natury gorsze od mężczyzn, ich cnoty muszą być równej jakości - jeśli nie równej mocy - bo inaczej cnota byłaby kwestią względną"47. Wszystkich zaś oceniać należy po tym, jak wypełniają swe naturalne obowiązki: najważniejszym, ostatecznym celem ich wysiłków powinien być rozwój ich własnych możliwości nabywania „godności płynącej ze świadomych cnót" kobiet, które kształcić należy tak, by „potrafiły samodzielnie myśleć i działać”49. Umysł ludzki po to rozwija się i doskonali, „by pojąć moralne powinności życia oraz znaczenie cnoty i godności”" ${ }^{\prime 0}$.

W drugiej kolejności Wollstonecraft pisała o przyrodzonej godności człowieka jako o nieodłącznej wartości natury ludzkiej, która jest przyczyną praw człowieka. Już miesiąc po opublikowaniu przez Edmunda Burke'a Rozważań o rewolucji we Francji Wollstonecraft opublikowała polemiczny tekst Wołanie o prawa człowieka, gdzie posługiwała się terminem wrodzo-

42 To zresztą Talleyrandowi dedykowane jest Wolanie o prawa kobiety; na pierwszej stronie można tu znaleźć słowa: „Dla Pana Talleyranda Perigorda, byłego biskupa Autun”.

${ }^{43}$ M. Wollstonecraft, Wołanie..., op. cit, s. 33.

${ }^{44}$ Ibidem. s. 34.

45 Ibidem, s. 35.

46 Ibidem, s. 41.

${ }^{47}$ Ibidem, s. 66.

${ }^{48}$ Ibidem.

${ }^{49}$ Ibidem, s. 92.

${ }^{50}$ Ibidem, s. 96. 
na godność człowieka. Prekursorka feminizmu widziała zatem to, czego nie zapisali twórcy amerykańskiej i francuskiej deklaracji praw człowieka, a co dla XX-wiecznego ujęcia praw człowieka jest zasadnicze: prawa i wolności człowieka mają swe źródło w godności ludzkiej. Wollstonecraft stanowczo podkreślała, iż ,istnieją pewne dziedziczone przy narodzinach prawa, które otrzymuje człowiek jako rozumna istota, wywyższona ponad zwierzęta za sprawą zdolności, które może kształtować" ${ }^{51}$. Jednocześnie odrzucała Burke'owski argument o tradycji jako wartościowym argumencie (pisząc wręcz o „służalczym stosunku do przeszłości”,52). Jako przykład podawała system niewolniczy, który skoro jest oparty na ,wiecznotrwałej podstawie” nigdy nie powinien zostać zniesiony. „I to tylko dlatego, że nasi przodkowie o ciasnych umysłach, nie rozumiejąc wrodzonej godności człowieka, zatwierdzili handel urągający rozumowi i religii" 53 . Podobnie stanowczo Wollstonecraft krytykowała nierówne tratowanie poddanych przez prawo karne oraz faworyzowanie przez prawo bogatych kosztem biednych ${ }^{54}$. Krytycznie postrzegała tradycyjne angielskie ujęcie idei wolności, uznając iż definiuje się ją przede wszystkim jako „bezpieczeństwo własności" ${ }^{55}$. Jednak nawet najbiedniejsi posiadają wartość wynikającą z faktu bycia człowiekiem - wrodzoną godność ${ }^{56}$. W podobnym ujęciu godność pojawiła się na kartach Wołania o prawa kobiety, gdzie autorka pisze o prawdziwej godności człowieka, którą odkryją dopiero królowie i szlachta oświeceni przez umys ${ }^{57}$.

Należy podkreślić, iż istotną rolę w myśli Wollstonecraft odgrywała idea rozumu oraz przekonanie o racjonalności człowieka ${ }^{58}$. Dzięki racjonalności człowiek jest bowiem w stanie samodzielnie kierować swym życiem. W wielu miejscach Wollstonecraft podkreślała wagę rozumu, m.in. apelując, by poprzez niewłaściwą edukację nie pozbawiać kobiety możliwości kształtowania

${ }^{51}$ Ibidem, s. 301-302.

52 Ibidem, s. 302.

${ }^{53}$ Ibidem.

54 (...) tylko majątek bogatego jest bezpieczny, człowiek pracujący w pocie czoła nie ma żadnej ucieczki przed uciskiem. Silny może bez przeszkód wejść do domu biednego - kiedyż to dom biednego byt twierdzą? (...) Nasze prawo karne karze śmiercia złodzieja kilku funtów, ale zabieranie człowieka siła nie jest już tak haniebnym wykroczeniem. Albowiem któż śmie podawać w wątpliwość czcigodne pozostałości prawa, które stanowiło, że życie jelenia jest świętsze niż człowieka? Ibidem, s. 303.

${ }^{55}$ Ibidem, s. 302.

${ }^{56} \mathrm{~W}$ taki sposób ciemiężony byl jedynie biedak, nie posiadajacy nic więcej niż wrodzona godność. Ibidem, s. 303.

${ }^{57} \mathrm{~W}$ oryginale: But for this epoch we must wait-wait, perhaps, till kings and nobles, enlightened by reason, and, preferring the real dignity of man to childish state, throw off their gaudy hereditary trappings.

${ }^{58}$ Aby mogły stać się szanowane, musza ćwiczyć swoja rozumność, na innej podstawie bowiem nie wyrośnie niezależność charakteru; chcę tu powiedzieć otwarcie, że kobiety musza uginać się jedynie pod władza rozumu, nie zaś być skromnymi niewolnicami opinii. M. Wollstonecraft, Wolanie..., op. cit., s. 98. 
swego umysłu, gdyż odziera ją to z godności ${ }^{59}$. Angielska pisarka ubolewała, iż kobiety „nigdy nie mają możliwości ćwiczyć własnego rozumu”, przez co nie mogą być niezależne". Co gorsza, wskutek tego nie mogą poczuć godności racjonalnej woli (dignity of a rational will), „która tylko Bogu się kłania”60. Należyta edukacja dałaby jednak szansę uzyskania „świadomej godności”, m.in. dzięki poczuciu niezależności od drugiej jednostki ${ }^{61}$. To dzięki takim przymiotom umysłu ludzie są $\mathrm{w}$ stanie docenić fakt rozwijania się i dążenia do prawdy ${ }^{62}$. O świadomej godności Wollstonecraft wspominała, opisując sytuację wdowy, na której ciąży obowiązek samotnego wychowania dzieci63.

W innym kontekście, dotyczącym kobiet zdobywających władzę, Wollstonecraft pisała o ich utraconej ,godności umysłu” ${ }^{64}$. O godności umysłu (dignity of a mind $)^{65}$ angielska pisarka wspominała też, krytykując kobiety za ich uwielbienie przyjemności, które to uczucie było wzbudzane wskutek wychowania kobiet. Za niegodne racjonalnej istoty uważała niecierpliwe pragnienie drugorzędnych rzeczy i pożądanie nowych przygód, zamiast zajmowania się swoimi powinnościami. Jest to jednak efekt kompletnie różnego wychowania - zupełne inne wzorce wpaja się chłopcom i dziewczynkom. „Jestem w pełni przekonana, że nie słyszelibyśmy o tych dziecinnych postawach, gdyby pozwolono dziewczętom korzystać $\mathrm{z}$ powszechnych praw (...), gdyby ten strach $\mathrm{w}$ dziewczętach (...) był traktowany w ten sam sposób, jak tchórzostwo u chłopców, to kobiety dość szybko zyskałyby więcej godności (...). Bez wiedzy nie może być moralności!’66

W kontekście wychowania i edukacji (krytykując porady w tym zakresie, jakie zawarł Jan Jakub Rousseau w swym dziele zatytułowanym Emil) Wollstonecraft łączyła z ideą godności charakter człowieka, pisząc, iż ci, którzy chcą „nadać charakterowi swej córki prawdziwej godności” ${ }^{67}$, zmuszeni są wychowywać swe dziecko zupełnie odmiennie od narzucanych popularnych wzorów postępowania. Wollstonecraft pisała o „godności charakteru” człowieka, której szkodzą niektóre przepisy prawa dotyczące dziedziczenia własności. Wollstonecraft domagała się równego prawa do dziedziczenia przez wszystkie dzieci niezależnie od starszeństwa i płci, ponieważ faworyzowanie

59 Wollstonecraft ówczesną sytuację nazywa błędnym systemem kobiecych obyczajów, który ograbia cała płeć z godności i przyporządkowuje brunetki i blondynki do kategorii uśmiechniętych kwiatów, które jedynie ozdabiaja ziemię. Ibidem, s. 101.

${ }^{60}$ Ibidem, s. 78 .

${ }^{61}$ Wollstonecraft pisała: ksztattujmy ich umysty, nałóżmy im zdrowe, wzniosłe cugle zasad i pozwólmy im uzyskać świadoma godność dzięki poczuciu, że sa podległe tylko Bogu. Ibidem, s. 79.

${ }^{62}$ I jeśli nie istnieje ta świadoma godność, która szeptałaby nam, że jesteśmy zdolni czerpać radość ze wznioślejszych przyjemności - głód prawdy wydaje się być zaspokojony. Ibidem, s. 305.

${ }^{63}$ Nie myśli już o tym, by się podobać; świadoma godność nie pozwala, by wzrosła $w$ dumę na skutek pochwat, jakie zbiera dzięki swemu postępowaniu. Ibidem, s. 97.

${ }^{64}$ Ibidem, s. 90.

${ }^{65}$ W polskim tłumaczeniu ,,powaga umysłu”.

${ }^{66}$ Ibidem, s. 112-113.

${ }^{67}$ Ibidem, s. 85. 
najstarszego syna ma opłakane skutki dla całej rodziny ${ }^{68}$. O godności Wollstonecraft wspominała także w powiązaniu z duszą człowieka ${ }^{69}$.

Jak jednak osiągnąć stan, w którym zapewniona będzie godność człowieka i jego prawdziwe szczęście? Także tu Wollstonecraft dawała odpowiedź mocno związaną z XX-wiecznym dyskursem o prawach człowieka. Drogą wiodącą ku polepszeniu rzeczywistości jest właściwe wychowanie i edukacja. Wollstonecraft o edukacji pisała, iż ,jest to takie na dziecku skupienie uwagi, które będzie powoli wyostrzało jego zmysły, kształtowało temperament, porządkowało wzruszenia, w miarę jak zaczną się burzyć, i poruszało rozumność, by zaczęła działać, nim ciało osiągnie dojrzałość"70. Dzięki temu człowiek będzie w stanie doskonalić umiejętności, w które wyposażył go Bóg: ,godność, jaką jest dążący ku lepszemu rozum”71, a którymi różni się od zwierząt. Ciągłe doskonalenie się, pomnażanie talentów otrzymanych przy narodzinach jest celem naszej egzystencji. Tymczasem część ludzkości, tj. kobiety, przez brak możliwości kształcenia się i samodzielnego życia, nie ma ku temu możliwości. Wollstonecraft zaznaczała (w kontekście kobiet, zatem tym bardziej należy to odnieść do ludzi jako takich bez względu na płeć), że „najważniejszym, ostatecznym celem ich wysiłków powinien być rozwój ich własnych możliwości nabycia godności płynącej ze świadomych cnót"72. Co gorsza jednak, nawet ci, którzy mają ku temu lepsze warunki, nie robią tego. W tym kontekście Wollstonecraft krytykowała warstwy najbogatsze, pisząc, iż „sposób wychowania ludzi bogatych zmienia ich zwykle w istoty próżne i bezbronne, nie wzmacniając rozwijających się umysłów ćwiczeniem w obowiązkach, które przydają godności ludzkim charakterom"73. W innym miejscu, kontrastując ze sobą niewolnicze, lecz łatwe życie w haremie, z wartościową egzystencją wolnego człowieka, Wollstonecraft stwierdzała, iż ludzkie życie winno rozwijać w nas te cnoty, które nadają godność rodzajowi ludzkiemu ${ }^{74}$.

68 Wollstonecraft apelowała, by sprawiedliwie dzielono majątek pośród wszystkie dzieci, w przeciwnym razie będzie to wiecznie niezdobyty szaniec, następstwo barbarzyńskich instytucji feudalnych, który umożliwia najstarszemu synowi obezwładniać talenty i uciskać cnotę! W ten sposób zaszczepia się w społeczeństwie wyzbyta męstwa służalczość. Ibidem.

${ }^{69}$ A jeśli godność kobiecej duszy jest równie watpliwa, jak zwierzęcej, jeśli rozumowi kobiet nie dostaje światla - które, skoro odmawia im się nieomylnego instynktu, kierowałoby ich postępowaniem - sq one z pewnościa najbardziej żałosnymi ze stworzeń (...). Jednak wyjaśnić, czemu Opatrzność obrała wobec nich taka drogę, wskazując niepodważalne powody, dla których uczyniła tak wielka część rodzaju ludzkiego odpowiedzialna i nieodpowiedzialna - to zadanie przerosłoby najbardziej wyrafinowanego kazuistę. Ibidem, s. 90.

${ }^{70}$ Ibidem, s. 60.

${ }^{71} \mathrm{~W}$ oryginale Wollstonecraft pisze: improveable reason is allowed to be the dignified distinction, which raises men above the brute creation.

72 Ibidem, s. 66.

${ }^{73}$ Ibidem, s. 43.

74 Wollstonecraft retorycznie pytała, czy maja bezczynnie przesypiać swe życie, pływajac w rozkoszach lub ospatym znużeniu, zamiast świadomie $i$ wprost dążć do rozsadnych przyjemno- 
Zatem wykorzystywanie rozumu, świadome kształtowanie swego charakteru to działania naturalne dla człowieka. Realizacja swych celów, doskonalenie swych umiejętności to godny sens życia. Dlatego angielska pisarka tak mocno krytykowała postrzeganie kobiet jako nieracjonalnych i kierujących się wyłącznie uczuciami oraz jako tych, których edukacja ma uczyć kokieterii, zalotów (,dlaczego umysł kobiety musi być zbrukany sztuką kokieterii”, pytała retorycznie Wollstonecraft ${ }^{75}$ ). Dlatego apeluje, by pozwolić, ,aby uczciwe serce wejrzało samo w siebie a wówczas umysł oświeci namiętność, by poddała się temu, co nieuniknione. Innymi słowy, pozwólmy chlubnemu dążeniu do cnoty i wiedzy wznieść umysł ponad te wzruszenia, które, nieokiełznane należycie, zamiast osładzać, puchar życia zaprawiają goryczą,"76. Odpowiednia edukacja i wychowanie, które właściwie ukształtuje umysł, pozwoli zapewnić kobiecie samodzielne życie, którego cechą jest właśnie godność ${ }^{77}$ (w innym miejscu Wollstonecraft pisała o działaniu charakteryzującym się równocześnie odpowiednią niezależnością i godnością $\left.{ }^{78}\right)$.

Równie krytycznie jak o życiu arystokracji czy edukacji kobiet, Wollstonecraft pisała o samym życiu współczesnych jej kobiet, które „są traktowane jak królowe tylko po to, aby potem, zwiedzione pozornym szacunkiem doprowadzone zostały do rezygnacji z naturalnych przywilejów". Angielska prekursorka feminizmu przyrównywała wręcz ich życie do egzystencji ptaków uwięzionych w klatkach, które nie mogąc latać, zajmują się wyłącznie „muskaniem swych piórek oraz przechadzaniem się ze sztucznym dostojeństwem z grzędy na grzędę"79. W zamian jednak za bezpieczeństwo, które zapewniają im mężczyźni, kobiety oddają dużo cenniejsze wartości takie, jak zdrowie czy wolność. A dopóki prawo będzie traktować kobiety jako istoty całkowicie zależne od mężczyzn (np. prawo spadkowe), trudno będzie zrezygnować z posiadanych powierzchownych przywilejów. Wollstonecraft uznała, iż w takiej sytuacji trudno oczekiwać od kobiet, by odrzucając je, znalazły spokojną godność rozumu, odnajdując dumę z przywilejów przyrodzonych człowiekowi ${ }^{80}$.

Będąc krytyczną wobec arystokracji, Wollstonecraft uważała, iż wartościowszą klasą jest klasa średnia, jako że składa się ona w większości z cnót

ści, i zwracać na siebie uwagę praktykowaniem cnót nobilitujących ludzkość? Ibidem, s. 70. W oryginale: (...) practising the virtues which dignify mankind?

75 Ibidem, s. 73

${ }^{76} \mathrm{~W}$ oryginale: Let the honest heart shew itself, and reason teach passion to submit to necessity; or, let the dignified pursuit of virtue and knowledge raise the mind above those emotions which rather imbitter than sweeten the cup of life, when they are not restrained within due bounds.

${ }^{77} \mathrm{~W}$ oryginale: That a proper education; or, to speak with more precision, a well stored mind, would enable a woman to support a single life with dignity.

${ }^{78}$ Ibidem, s. 156.

${ }^{79}$ Ibidem, s. 104.

${ }^{80}$ W polskim thumaczeniu ,spokojną powagę rozumu”. Ibidem; w oryginale: calm dignity of reason. 
i umiejętności. Natomiast pochodzący z tej klasy mężczyźni mogą rozwijać swe umiejętności i mają szansę godnego wysiłku (opportunity of exerting themselves with dignity) przez ten trud, który naprawdę doskonali istotę rozumną ${ }^{81}$.

Podsumowując, należy zaznaczyć, iż w pracach Wollstonecraft znaleźć można liczne pomysły i idee, które dla obywatela XX w. są przestarzałe i archaiczne. Nie mogła się tego ustrzec ze względu na ograniczenia epoki, w której tworzyła. Część z jej postulatów ma charakter utopijny, a realizacja niektórych (równość ekonomiczna i walka z własnością prywatną) przyniosły cierpienia całych narodów i społeczeństw.

Bez wątpienia jednak ważny jest jej wkład w rozwój doktryny feminizmu i angielskiego liberalizmu. Jako jedna z pierwszych szermowała ideą godności dla uzasadnienia równości kobiet i mężczyzn. Godność człowieka stała się ważnym elementem dla całej myśli feministycznej. Widać jednak, że myśl Wollstonecraft nie ogranicza się jednak do walki o równouprawnienie, lecz wychodzi daleko poza ramy tradycyjnej literatury feministycznej. Wreszcie, co najważniejsze, jej argumentacja jest dużo bliższa XX-wiecznej myśli polityczno-prawnej niż tej, która kształtowała się u zarania epoki praw człowieka i obywatela. W wielu miejscach Wollstonecraft używała idei godności jako wartości, która nadaje nam sens istnienia lub raczej dążenie do jej zachowania nadaje nam sens istnienia. Pojawia się tu skojarzenie ze słynną frazą Ernsta Blocha o ,chodzeniu wyprostowanym" $"$.

Umiłowanie wolności (,wolność jest matką cnoty”"83) i równości praw publicznych, niezłomna wiara w rozum i racjonalność, wreszcie świadomość wagi edukacji ${ }^{84}$ dla rozwoju jednostki jako podstawowego narzędzia kształtowania $^{85}$ i warunku istnienia możliwości realnego wyboru (a nie tylko formalnego), stawiają Wollstonecraft, wśród filozofów najważniejszych dla myśli liberalnej, obok takich wybitnych twórców jak John Stuart Mill (który także mocno nawoływał do zrównania praw kobiet, ale - co warto podkreślić - pół wieku później). Klasyczny liberalizm podkreśla przecież, iż rozwój jednostki to także rozwój całej ludzkości. Identycznie kwestię tę ujmowała Wollstonecraft, pisząc, iż polepszenie pozycji kobiet, to polepszenie pozycji całej ludzkości ${ }^{86}$.

${ }^{81}$ M. Wollstonecraft, Wołanie..., op. cit., s. 106.

${ }^{82}$ E. Bloch, The principle of hope, Cambridge 1996, s. 471.

${ }^{83}$ M. Wollstonecraft, Wolanie..., op. cit., s. 80.

${ }^{84}$ Jeśli poprzez mądra polityke szerzona będzie wolność, tedy ludzkość - w tym kobieta - stanie się bardziej roztropna, świadoma i cnotliwa. Ibidem.

${ }^{85}$ Dla Wollstonecraft edukacja to pierwszy krok do tworzenia istoty kroczącej stopniowo ku doskonałości. Ibidem, s. 101.

${ }^{86}$ Czas dokonać przewrotu $w$ kobiecych obyczajach $i$ wychowaniu; czas zwrócić im utracona godność $i$-jako części gatunku ludzkiego-umożliwić im naprawienie świata poprzez naprawienie samych siebie. Ibidem, s. 90. 


\section{Godność jako wysoka ranga przynależna wszystkim. Gregory Vlastos} i Jeremy Waldron. Gregory Vlastos ${ }^{87}$ swoją koncepcję godności jako równej rangi dla wszystkich przedstawił na marginesie rozważań dotyczących problemów odróżniania sprawiedliwości od równości. Vlastos wskazał na generalne trudności z wyjaśnieniem, czym jest równość oraz co oznacza twierdzenie, że wszyscy ludzie rodzą się równi. Aby odpowiedzieć na te pytania, sięgnął do teorii praw naturalnych. Uznał, iż prawa naturalne to po prostu prawa człowieka, zaznaczając jednak, iż nie traktuje ich w sensie trywialnym, lecz w sposób ambitny, stawiając przed ich treścią i funkcją wysokie wymagania ${ }^{88}$. Vlastos zadał trzy pytania: Jaki jest zasięg tych praw? Co z formułami sprawiedliwości? Czy prawa naturalne są absolutne ${ }^{99}$ Uznał, iż aby określić możliwe wyjątki od tych praw, trzeba znaleźć powody istnienia praw człowieka, które będą jednocześnie jedynymi przyczynami dla sprawiedliwych wyjątków od praw człowieka.

Ten amerykański filozof uznał, iż ludzka wartość każdego człowieka jest równa, choć nierówne mogą być jego zasługi ${ }^{90}$. Jednak mimo różnicy w zasługach (lub zaletach) żaden członek społeczeństwa nie może być z niego wykluczony ani pozbawiony określonych praw. Dla Vlastosa był to dowód, iż społeczeństwa XX-wieczne przypominają społeczeństwa kastowe, tyle że $\mathrm{z}$ jedną unikatową kastą społeczną ${ }^{11}$. Uznanie każdego człowieka za samoistną wartość (co w końcu leży u podstaw koncepcji godności) jest niezależne od jego czynów - a to powoduje niezbywalność godności ${ }^{92}$. W takiej jednostatusowej (single-status) wspólnocie praw osobistych nie traktuje się proporcjonalnie do zasług i nie uzasadnia się ich posiadania zasługami. Ich jedynym uzasadnieniem może być wartość (infinitive value), jaką każdy z nas ma $\mathrm{z}$ racji bycia osobą (individual human worth). W takim kontekście Vlastos przypomniał zdanie Immanuela Kanta, który stwierdził, iż każdy człowiek jest celem samym w sobie. Taką wartość Vlastos rozpatrywał w dwóch ujęciach: jako ideę doświadczaną albo odczuwaną jako wartościowa przez ludzi, albo jako wybraną spośród możliwych alternatyw ${ }^{93}$. Vlastos wykorzystał te dwa czynniki w dalszych rozważaniach. Pierwsze ujęcie połączył z pojęciem szczęścia w platońskim znaczeniu eudajmonii, choć jak przyznał lepiej określać to jako welfare lub well-being, czyli powodzenie i pomyślność. Drugie ujęcie to według Vlastosa nic innego jak freedom, ale także choices, czyli wybory. Ludzkie powodzenie i wolność są aspektami indywidualnej egzystencji

\footnotetext{
${ }^{87}$ Gregory Vlastos (1907-1991) - amerykański filozof i wykładowca Uniwersytetu Princeton.

${ }^{88}$ G. Vlastos, Justice and Equality, [w:] Theories of Rights, red. J. Waldron, Oxford 1985, s. 44.

89 Ibidem, s. 45.

${ }^{90}$ The human worth of all person is equal, however unequal may be their merit. Ibidem, s. 51 .

${ }^{91}$ Ibidem, s. 54.

${ }^{92}$ Ibidem, s. 55.

${ }^{93}$ Ibidem, s. 56.
} 
i są one tak samo niepowtarzalne i unikatowe jak ta egzystencja. Tak więc dla Vlastosa ludzka wartość (human worth) oznaczała ludzkie powodzenie i wolność jako indywidualna wartość ${ }^{94}$.

Kolejnym zagadnieniem, które poruszył Vlastos, była kwestia równości ludzkiej wartości, która jest uzasadniona na gruncie równych praw człowieka. By rozwinąć tę kwestię, Vlastos posłużył się opowieścią o Marsjaninie, który odwiedza Ziemię i próbuje zrozumieć, dlaczego racjonalne istoty pragną takich samych praw dla elit $i$ dla hołoty. Odpowiedzią jest oczywiście ludzka wartość, jednak według Vlastosa odpowiednio nieskomentowana będzie wydawać się niezrozumiała. Wytłumaczeniem tego jest uwolnienie od bólu przysłowiowego kongresmana i bezrobotnego - mających taką samą wewnętrzna wartość, ale inną wartość instrumentalna ${ }^{95}$.

Podsumowując, według Vlsatosa pomyślność jednego człowieka jest warta tyle samo co pomyślność każdego innego. Podobnie, wolność jednego człowieka jest tak samo wartościowa jak wolność każdego innego. I to bez względu na skutki tych wyborów, choć oczywiście najlepiej byłoby, aby były dobre. Ale to nie jest warunek, który musi wystąpić, aby wolność wyboru ocenić pozytywnie. Zatem prawo do pomyślności jednego człowieka jest równe prawu drugiego człowieka. $Z$ tego też powodu mamy tak zróżnicowane prawa do różnorodnych wolności ${ }^{96}$. Natomiast teza wcześniejsza jest uzasadnieniem dla licznych praw socjalnych. Vlastos uważał, iż wierzymy w równą wartość indywidualnej wolności i pomyślności szczęścia, czyli equal human worth równa się equal worth of human well-being and freedom, ale ta równa wartość człowieka nie może być zredukowana wyłącznie do równej wartości ludzkiej pomyślności i wolności. Pierwsza i druga teza według Vlastosa są wystarczającymi fundamentami praw człowieka. Natomiast pozostałe wartości mogą być dodatkowymi.

Do koncepcji Vlastosa nawiązał anglosaski filozof i teoretyk prawa Jeremy Waldron. Waldron stwierdził, iż godność jest to ,powszechna dla wszystkich wysoka ranga szlachectwa”. Jednocześnie godność jest „terminem, który wyjaśnia nam coś o statusie człowieka oraz jest także łącznie używany by dostarczyć żądania, aby ten status był rzeczywiście respektowany"97.

Waldron uznał, iż w pewnym momencie historycznym nastąpiło przewartościowanie kwestii godności, ponieważ nastąpiła ogromna zmiana w używaniu terminu godność, tj. w sposobie użycia ${ }^{98}$. Godność stała się kategorią obejmującą nie nielicznych, ale wszystkich. Jednak jej istota (treść) pozosta-

\footnotetext{
${ }^{94}$ Ibidem, s. 57.

${ }^{95}$ Ibidem, s. 58

${ }^{96}$ Ibidem, s. 59 .

${ }^{97}$ J. Waldron, Dignity and Rank, „European Journal of Sociology”, t. 48, nr 2, sierpień 2007,

${ }^{98}$ Ibidem, s. 220.
} s. 205. 
ła relatywnie niezmieniona. Stąd też Waldron uważał, iż pogląd Vlastosa na godność może rzucić nowe światło na istotę godności - w postaci użytecznego związku „niezależnego" znaczenia godności (powiązanej z wysokim statusem) z egalitariańskim poglądem na godność. Zamiast stanu przeciwieństwa (elitarna idea godności przeciw egalitarnej idei godności) mamy dynamiczną relację w ramach reversal-of-rank-conception ${ }^{99}$. Według Waldrona koncepcja Vlastosa ma istotne znaczenie $\mathrm{z}$ dwóch względów. Po pierwsze, używamy idei godności, aby zrozumieć ideę ludzkiej wartości i jej poszanowania. Po drugie, aby zrozumieć szczegóły praw, które posiadają dziś wszyscy, nie tylko szlachta.

Jeremy Waldron wskazał, iż godność należy traktować w sposób dwojaki. Po pierwsze jako zasadę moralną, po drugie jako zasadę prawa. Odpowiednio można ją badać i analizować w dwojaki sposób: szukając opisu i wyjaśnień jej istoty w tekstach filozoficznych lub badając teksty prawne i preambuły do rozmaitych deklaracji praw i wolności człowieka. Pytanie jednak, którą z tych ścieżek należy podążać najpierw. Ponieważ godność w sferze prawa „,czuje się jak u siebie w domu" 100 , Waldron uważa, iż rozpocząć należy od interpretacji tekstów prawnych, uznając, iż ,godność nie musi być traktowana w pierwszej kolejności jako zasada moralna”, ponieważ „prawo zawiera, rozwija i tworzy pewne idee, nie tylko zaś pożycza je od moralności" ${ }^{\prime 101}$. To przekonanie wynika z jego stosunku do pochodzenia idei godności.

Odpowiedź na pytanie, z jaką sferą (filozoficzną czy prawną) będziemy przede wszystkim wiązać ideę godności, będzie miała istotne skutki dla pojmowania jej istoty. Dla Waldrona, godność jako idea konstruktywna (podobnie jak użyteczność) ma dwie funkcje: fundacyjną i objaśniającą ${ }^{102}$.

Waldron przypomniał, że w historii filozofii znajdziemy wiele opinii, iż godność to kwestia statusu. Jednak status to koncepcja prawna. W prawie idea godności powiązana była z rangą społeczną: godność króla, godność biskupa, godność urzędnika. Waldron zauważył, że współczesna nam idea godności człowieka zawiera w sobie te historyczne reminiscencje. Godność ludzka to bowiem idea wysokiej i równej rangi wszystkich istot ludzkich (high and equal rank of every human person ${ }^{103}$ ). Tak rozumiana godność jest bardzo blisko związana z ideą praw podstawowych: jako ich fundament, jako treść niektórych z nich oraz dla części z nich jako oddziałująca na strukturę i formę ${ }^{104}$.

Na marginesie warto wskazać, iż niestety tak jak w wypadku wielu innych idei fundamentalnych dla filozofii prawa, jak wolność, równość czy

\footnotetext{
${ }^{99}$ Ibidem, s. 222.

100 J. Waldron, Dignity, Rank and Rights, „The Tanner Lectures on Human Values” 2009, s. 209.

${ }^{101}$ Ibidem, s. 210.

102 Ibidem, s. 209.

${ }^{103}$ Ibidem, s. 210 .

${ }^{104}$ Ibidem.
} 
sprawiedliwość, także godność jest pojęciem wieloznacznym, definiowanym w bardzo rozmaity sposób i używanym w wielu kontekstach. Ta wieloznaczność jednak nie musi być od razu oceniana negatywnie. Pokazuje ona tylko złożoność idei godności. Na potwierdzenie tych słów wystarczy sięgnąć do Karty praw podstawowych. Godność pojawia się tam już w preambule, gdzie wymieniona jest jako jedna z fundamentalnych wartości, na których jest zbudowana Unia Europejska ${ }^{105}$. Ponadto jest to nazwa Tytułu I, na który składają się takie uprawnienia jak: godność człowieka (art. 1), prawo do życia (art. 2), prawo człowieka do integralności (art. 3), zakaz tortur i nieludzkiego lub poniżającego traktowania albo karania (art. 4) oraz zakaz niewolnictwa i pracy przymusowej (art. 5). Wreszcie godność pojawia się w kontekście warunków pracy, które nie mogą jej naruszać ${ }^{106}$. Występuje więc dokładnie w tych trzech rolach, o jakich pisał Waldron.

Ponadto wskazywał on na pewien dualizm w pojmowaniu idei godności. $Z$ jednej strony rozumiemy ją jako niezbywalną i przyrodzoną każdemu człowiekowi, z drugiej strony rozumiemy ją jako pewien cel do osiągnięcia ${ }^{107}$. Słusznie jednak Waldron uznał to za sprzeczność pozorną. Następnie zajął się dwoistością idei godności jako fundamentu praw podstawowych i jako treści niektórych $\mathrm{z}$ nich - dualizm ten uznawał wręcz za naturalny. Tak więc równocześnie z tym, że godność jest fundamentem praw człowieka, ludzie mają osobne prawo do ochrony przed poniżającym traktowaniem oraz przed naruszeniem godności osobistej. Waldron podkreślał jednak, iż nie jest zwolennikiem tezy, że fundamentem prawa człowieka jest wyłącznie jedna $\mathrm{z}$ takich wartości jak godność, równość, autonomia jednostki czy bezpieczeństwo. Uznawał fakt, że godność jest traktowana równocześnie jako ogólny cel praw człowieka i niektóre z praw mogą być szczególnie nastawione na ochronę pewnych aspektów godności. Jednak podkreślał, że nie jest zwolennikiem traktowania godności jako celu praw człowieka. Wolał widzieć w niej normatywny status, zaś niektóre z praw człowieka jako związane z nią lub jej pochodne (ale nie jako podporządkowane jej osiągnięciu) ${ }^{108}$.

105 (...) Unia jest zbudowana na niepodzielnych, powszechnych wartościach godności osoby ludzkiej, wolności, równości i solidarności; opiera się na zasadach demokracji i państwa prawnego. Dziennik Urzędowy Unii Europejskiej z 30.03.2010, C 83/391.

${ }^{106}$ Art. 31 Należyte i sprawiedliwe warunki pracy

1. Każdy pracownik ma prawo do warunków pracy szanujących jego zdrowie, bezpieczeństwo i godność. Ibidem.

107 Tak w preambule do Powszechnej Deklaracji Praw Człowieka, która najpierw odwołuje się do nieskończonej walki o wolność i godność, aby dalej uznać przyrodzoną godność człowieka jako podstawę wolności, sprawiedliwości i pokoju na świecie. http:/www.unesco.pl/fileadmin/ user_upload/pdf/Powszechna_Deklaracja_Praw_Czlowieka.pdf

${ }^{108}$ I will actually argue against a reading of the dignity idea that makes it the goal or telos of human rights. I think it makes better sense to say that dignity is a normative status and that many human rights may be understood as incidents of that status. (The relation between a status and its 
Następnie Waldron wskazał na rozróżnienie między godnością jako generalnym statusem a szczególnymi prawami, które ten status chronią. Wśród tych szczególnych praw dokonał podziału na pozytywne (afirmatywne) i negatywne. Pierwszą grupę stanowić będą przepisy, które zawierają pewne nakazy. Przykładem jest prawo do odpowiedniego i zadowalającego wynagrodzenia, zawarte $\mathrm{w}$ art. 23 u. $3 \mathrm{PDPC}^{109}$. Natomiast druga grupa to przepisy zakazujące pewnych działań. Do drugiej grupy zaliczył zakaz poniżającego traktowania (dodać można jeszcze zakaz tortur) ${ }^{110}$.

Godność człowieka w teorii praw człowieka jest uznawana za fundament praw podstawowych. Waldron wątpił jednak, czy to oznacza godność pojmowaną jako ideę moralną. Konwencje międzynarodowe wskazują bowiem w swych preambułach prawne podstawy uprawnień i niekoniecznie taka normatywna koncepcja (godność w ujęciu normatywnym) musi oznaczać odwołanie się do idei o charakterze moralnym ${ }^{111}$. Jako analogię do takiego ujęcia godności Waldron podał przykład rozmyślań Hanny Arendt o równości w starożytnej Grecji. Waldron przyznał, iż wielu filozofów jest przekonanych, że to właśnie godność jako idea moralna tworzy podstawę praw człowieka. Jako przykład wskazuje myśl Jamesa Griffina, który w tym celu zaadaptował XVwieczną ideę godności Pico Della Mirandoli. Dla Griffina istotą godności jest umiejętność człowieka bycia tym, kim zechce, czemu filozof ten przypisuje znaczenie normatywne. Gdy Griffin pisał, że ochrona naszych praw skutkuje poszanowaniem naszych decyzji ${ }^{112}$, Waldron uważał, iż takie ujęcie zbliża się do koncepcji godności jako statusu.

Tymczasem dla Waldrona status (godności człowieka) nie był celem, status raczej składa się z pewnego zespołu praw, aniżeli określa je jako instrumentalne w stosunku do siebie narzędzia ${ }^{113}$. W ten sposób Waldron opisywał kształt godności nie przez pryzmat prostego fundamentu praw człowieka, a jako dużo bardziej złożone zjawisko, które ma fundamentalny charakter dla praw podstawowych, ale jego istota i funkcje wychodzą daleko poza formułę podstawy.

Waldron wiązał ideę godności z zachowaniem i postawą człowieka. Odwoływał się tu do Ernsta Blocha, który w kontekście godności człowieka pi-

incidents is not the same as the relation between a goal and the various subordinate principles that promote the goal.). J. Waldron, Dignity, Rank... op. cit., s. 212.

${ }^{109}$ Art. 23 u. 3 PDPC:

Każdy pracujący ma prawo do odpowiedniego i zadowalającego wynagrodzenia, zapewniającego jemu i jego rodzinie egzystencję odpowiadającą godności ludzkiej i uzupełnianego w razie potrzeby innymi środkami pomocy społecznej.

${ }^{110}$ Art. 5 PDPC:

Nie wolno nikogo torturować ani karać lub traktować w sposób okrutny, nieludzki lub poniżający.

111 J. Waldron, Dignity, Rank... op. cit., s. 214.

112 Ibidem, s. 215.

${ }^{113}$ Ibidem. 
sał o „chodzeniu wyprostowanym”. Podkreślił, że użycie tego terminu często wiąże się z pewnym wyobrażeniem o zachowaniu lub postawie człowieka często mówimy o godnym zachowaniu, mając na myśli pewne dostojeństwo, wręcz majestatyczność. Rozumianym jednak nie w kontekście wyniosłości, lecz raczej prawości, wzniosłości i powagi, jako dbałość o siebie i swoją prezencję, o swoje dobre imię i samokontrolę jako przeciwieństwo podłości ${ }^{114}$. Łatwiej to zrozumieć, jeśli uzmysłowimy sobie, że godność pojmujemy często jako pewną rangę, $\mathrm{z}$ którą powiązany jest autorytet i szacunek ${ }^{115}$.

Takie generalne postrzeganie godności jako możności (lub umiejętności) zachowania ,wyprostowanej postawy” jest silnie zaznaczone zwłaszcza w wielu szczegółowych prawach podstawowych o ,godnościowym” charakterze - np. zakazie poniżającego traktowania. Z tego też powodu Waldron uważał, że zajmując się ideą godności, trzeba nie tylko połączyć szczegółowe i generalne pojmowanie godności, ale zrobić to tak, by rzuciło nowe światło na Blochowskie pojmowanie godności. Właściwe podejście do idei godności wyjaśni nie tylko jej ogólny status, rozumiany jako godne zachowanie, ale też jako zakaz poniżającego i nieludzkiego traktowania. Taki cel stawiał Waldron swej koncepcji godności jako wysokiej rangi (dignity as a high-ranking status), którą porównywał do szlachectwa - rangi przypisanej dziś każdemu człowiekowi, równo bez żadnej dyskryminacji - ,szlachectwa dla każdego"116.

Waldron, konstruując swoją teorię godności, musiał oczywiście odnieść się do Kantowskiego pojmowania godności, którą ten zawarł m.in. w Uzasadnieniu metafizyki moralności. Waldron nieco odmiennie interpretował jego koncepcję oraz wskazywał na te jej elementy, które mogą być argumentami za pojmowaniem godności jako wysokiego statusu. Punktem wyjścia tych rozważań jest określenie godności jako „wartości bezcennej”. Jednak Waldron wskazywał na dwie istotne uwagi. Po pierwsze uznał, że niemiecka die Würde jest dużo bliższa angielskiemu słowu worth aniżeli dignity (świadomie idąc pod prąd długoletniej tradycji translatorskiej). Po drugie, „bezcenna wartość” oraz ,przyrodzona, nienegocjowalna i niezbywalna godność przynależna każdej istocie ludzkiej"117 są istotnymi ideami, jednak Waldron wątpił, czy jest jakiś decydujący argument, aby obie określać mianem ,godności”118. Waldron widział zupełnie inny związek między tymi wartościami. Człowiek ma godność (w znaczeniu Waldronowskiego statusu), ponieważ ma (jako człowiek) „wartość bezcenną” (czyli Kantowską Würde). Ujmuje te idee zatem jako wynikające jedna z drugiej (genuine derivation), a nie jako synonimy. Dla Wal-

${ }^{114}$ Ibidem, s. 214-215.

115 Ibidem, s. 215.

${ }^{116}$ Ibidem, s. 216.

${ }^{117}$ Intrinsic non-negotiable non-fungible worth that inheres in every human being in virtue of his or her moral capacity. Ibidem, s. 218.

118 Ibidem. 
drona ma to określone skutki. Godność jako wartość można promować lub chronić, natomiast w przypadku godności jako statusu szanujemy i honorujemy osobę, która ten status posiada ${ }^{119}$.

Waldron uważał, iż rozważania Kanta o godności są niejednoznaczne. Fundament ludzkiej wartości wymaga poszanowania (respect), ale nie jest to szacunek do człowieka jako takiego, lecz do jego zdolności bycia moralnym (rozróżniania dobra od zła moralności). Nie jest to zatem szacunek osoby, lecz pewnej jej cechy ${ }^{120}$. Waldron uznawał to za argument, który może służyć poparciu jego koncepcji godności. Podobnie jak te fragmenty Kantowskiej doktryny, w których o godności pisze w sposób dużo bardziej zbliżony do idei szlachectwa.

Stéphanie Hennette-Vauchez i zasada godności ludzkiej końca XX w. Francuska profesor prawa Stéphanie Hennette-Vauchez w swych rozważaniach postawiła tezę, iż rozumienie godności człowieka pod koniec XX w. miało niewiele wspólnego z koncepcją godności, która ukształtowała się bezpośrednio po II wojnie światowej. Zasada godności ludzkiej końca XX w. (HDP - human dignity principle) była bowiem raczej związana ze starożytną koncepcją dignitas. Co więcej, jedna i druga idea skutkowała ograniczeniem wolności osobistej. Na potwierdzenie swej hipotezy Hennette-Vauchez wskazała trzy grupy argumentów. Po pierwsze, obie idee pełniły te same funkcje, których podstawą są obowiązki, a nie prawa. Po drugie, miały taką samą strukturę (obowiązków przeciwko obowiązkom). Po trzecie, były niezbywalne. Zwolennicy takiego pojmowania godności odchodzą od jej właściwości (symbolicznych czy instrumentalnych) w kierunku wzmocnienia na nowo praw naturalnych jako ostatecznej podstawy porządków naturalnych. W takim kontekście Hennette-Vauchez uznała zasadę godności ludzkiej za bardzo kontrowersyjną i niezadowalającą instytucję ${ }^{121}$.

Francuska konstytucjonalistka zgodziła się z przywoływaną we wstępie artykułu tezą Jamesa Q. Whitmana, wedle którego 2. połowa XX w. to era idei godności. Jednak Hennette-Vauchez była niezwykle krytyczna w stosunku do przyczyn popularności tej instytucji zarówno w prawie pozytywnym i orzecznictwie, jak i filozofii i teorii prawa, uznając iż jest to efekt niekonkretności idei, sakralizacji tego terminu i jego uniformizacji ${ }^{122}$.

Hennette-Vauchez podkreśliła, iż w stosunku do idei godności panuje sporo rozbieżności. Największe zaś miały miejsce w kwestiach najistotniejszych, tj. w odniesieniu do istoty i genezy idei godności. Jedni badacze, odwołu-

${ }^{119}$ Ibidem.

${ }^{120}$ Ibidem, s. 218-219.

${ }^{121}$ S. Hennette-Vauchez, A Human Dignitas? The Contemporary Principle of Human Dignity as a Mere Reappraisal of an Ancient Legal Concept, „EUI Working Papers” Law 2008/18, s. 3.

${ }^{122}$ Ibidem. 
jąc się do starożytnych źródeł, rozumieją istotę godności przede wszystkim jako ograniczenie (constraint), czyli ideę obowiązków i zobowiązań jednostki. Inni, sięgając do filozofii Kanta, definiują godność jako upodmiotowienie (empowerment) i określają ją jako ideę praw jednostki i jej autonomii. Ponadto, coraz częściej godność rozpatrywana jest na trzech poziomach: godność jednostki, godność grup i godność całej ludzkości. Z powyższych względów poszukiwanie odpowiednio konkretnej definicji może być właściwie niekończącym się zajęciem ${ }^{123}$.

Podobnie spore rozbieżności występują w teorii i filozofii prawa w odniesieniu do genezy zasady godności ludzkiej (HDP). Najczęściej wskazuje się na traumę związaną ze zbrodniami popełnionymi w czasie II wojny światowej i w takim kontekście godność człowieka jest traktowana jako fundament praw człowieka. Jednak według Hennette-Vauchez zbyt duże skupienie się na takim ujęciu godności pomija dwa ważne aspekty ewolucji, jak dokonała się od 1945 r. Po pierwsze, pomija się istotne wzmocnienie funkcji godności jako podstawy obowiązków (obligation grounding function), które nastąpiło kosztem funkcji godności jako podstawy praw podmiotowych (rights-founding function). Po drugie, zasada godności ludzkiej końca XX w. jest w wielu aspektach odbiciem starożytnej koncepcji dignitas ${ }^{124}$.

W ten sposób Hennette-Vauchez wskazała, iż właściwie możemy mówić o trzech ideach czy też koncepcjach godności jednostki ludzkiej funkcjonujących w teorii i praktyce prawa: starożytnej koncepcji dignitas, powojennej idei godności równej dla wszystkich ludzi oraz zasadzie godności osoby ludzkiej (dignity of a human person) z końca XX w.

Jak już wspominano wcześniej, Hennette-Vauchez podkreślała mocny związek między współczesną ideą godności a starożytną koncepcją dignitas. Dla obu polityczno-aksjologiczne pozytywne aspekty zasady godności ludzkiej jako reakcji na zbrodnie nazistowskie nie mogą być traktowane jako legitymizujący fundament. Według Hennette-Vauchez zasadę godności ludzkiej lepiej opisać jako application of a contingent and inegalitarian organizational principle to the social world ${ }^{125}$. W takim ujęciu zasada godności może być opisywana w dwóch ujęciach: teoretycznym (godność jako status) i technicznym. Francuska konstytucjonalistka stawia hipotezę, iż obie idee godności mają te same funkcje, strukturę i konsekwencje.

Następnie Hennette-Vauchez odnosiła się do teoretycznych koncepcji genezy XX-wiecznej godności, które powstały w 2. połowie XX w. W pierwszym rzędzie skomentowała koncepcję Jamesa Q. Whitmana, który opisał historię idei godności jako ewolucję od statusu społecznego do człowieczeństwa jako statusu. Whitman jako pierwszy uznał błąd w twierdzeniu, iż zasada

\footnotetext{
${ }^{123}$ Ibidem, s. 4.

124 Ibidem, s. 5.

125 Ibidem, s. 6.
} 
godności ludzkiej (końca XX w.) jest osadzona w doświadczeniach II wojny światowej. Według tego amerykańskiego teoretyka prawa była ona bowiem znacznie mocniej zakorzeniona $w$ starych normach prawnych dotyczących honoru. Na marginesie warto zauważyć, iż takie ujęcie idei godności jest podobne do koncepcji Gregory'ego Vlastosa i Jeremy'ego Waldrona. Dla Hennette-Vauchez koncepcja Whitmana jest początkiem nowego spojrzenia na ideę godności. Równocześnie jednak podkreśliła, iż Whitman nie zauważył zaburzeń i ignoruje różnice między powojennym ujęciem idei godności a ujęciem z końca XX w. Hennette-Vauchez zgodziła się z nim, iż dziś koncepcja godności opiera się na idei statusu (conceptual construction of humanity as a status $\left.^{126}\right)$.

Koncepcja Whitmana zakładała, iż starożytne normy były na przestrzeni wieków stosowane do coraz szerszego kręgu podmiotów (w dosłownym tłumaczeniu: podnoszone do wyższego poziomu - levelling up) do momentu, aż zaczęły być stosowane do całej ludzkości. W ten sposób w końcu XX w. idea godności stała się wysokim statusem społecznym przynależnym każdemu (high social status for everybody). Jednakże Hennette-Vauchez zauważyła, że proces opisany przez Whitmana doprowadził do innych skutków: uznania i proklamowania przynależności do rodzaju ludzkiego (common humanity, common belonging of all individuals) oraz że na podstawie pewnych przesłanek można wskazywać na zachodzące równocześnie, ale odrębne od siebie dwa zjawiska: upowszechnienie i rozciągnięcie zakresu idei honoru oraz pojawienie się idei przyrodzonej i niezbywalnej godności równej dla wszystkich.

Nie można kwestionować procesu upowszechnienia wysokiego statusu społecznego, lecz Hennette-Vauchez nie zgadzała się z tezą, iż taka generalizacja osiągnęła wszystkie konsekwencje wskazane przez Whitmana. Po pierwsze, zaprzecza, by starożytne normy honoru były stosowane do wszystkich, po drugie wskazuje, że nie zostały one zawarte w idei godności. Ta generalizacja nigdy nie była procesem kompletnym, ponieważ prawna logika norm honoru nadal obowiązuje jedynie częściowo i niekompletnie. Jako przykłady Hennette-Vauchez podała współczesne koncepcje godności niektórych zawodów czy prawa obywatelskie. Francuska myślicielka stanęła na stanowisku, iż ta ewolucja nie wykluczała istnienia równoległej (ale odrębnej) ścieżki ewolucji koncepcji godności jako wartości równo należącej do wszystkich ludzi. W ten sposób Hennette-Vauchez postawiła hipotezę o istnieniu dwóch odrębnych ścieżek ewolucji idei godności. Pierwsza, mająca początek w starożytności, w drodze upowszechniania statusu i idei honoru doprowadziła do współczesnego kształtu idei godności. Drugi proces był równoległy i rozpoczął się na początku XIX w. Doprowadził do idei godności jako twierdzenia, iż każdy jest człowiekiem oraz indywidualnością. Według Hennette-Vauchez

${ }^{126}$ Ibidem, s. 7. 
Whitman, nie dostrzegając różnicy między tymi procesami, rozpatruje się często łącznie ich efekty. Tymczasem mogą mieć one związek albo ze statusem (wtedy ich istotą jest nierówność), albo z człowieczeństwem i równością rozumianą jako przynależność do rodzaju ludzkiego ${ }^{127}$. Idea, że wszyscy ludzie mają prawa tylko z tego powodu, że są ludźmi, powstała w czasach wielkiej rewolucji francuskiej i rozwijała się do $1945 \mathrm{r}$. Hennette-Vauchez zauważyła, że ten brak rozróżnienia jest dosyć częsty, np. w Prawach Podstawowych Izraela z 1992 r. (Izrael Basic Law: Human Dignity and Liberty).

Wydaje się jednak, iż Hennette-Vauchez nie jest konsekwentna w opisie i ocenie koncepcji Whitmana, gdyż pisze o postępującej utracie znaczenia statusu (równoczesny proces uznawania że wszyscy ludzie są równi). Starożytne pojęcie godności ewoluowało - grupa ludzi chronionych ze względu na status rosła, ale cechy tego statusu (wrodzone i wewnętrzne - nierówne) nie zniknęły.

Dla Hennette-Vauchez zasada godności ludzkiej była kolejną zasadą odpowiedzialną wyłącznie za wyrażenie idei szacunku do wszystkich osób ze względu na ich człowieczeństwo. Taka koncepcja różni się znacznie od starożytnej idei dignitas, jeśli tylko jest w swej istocie egalitarna. Dlatego nie można zgodzić się z Whitmanem, że idea godności jest potomkiem starożytnej dignitas. Koncepcja Whitmana nie definiuje powojennej koncepcji godności, ale rzuca wartościowe światło na koncepcję godności końca XX w. Właśnie ta koncepcja wyjaśnia zakaz rzucania karłami, karne zarzuty w stosunku do miłośników praktyk sadomachosochistycznych czy ograniczenie prawa pacjenta do odmowy dalszego leczenia.

Hennette-Vauchez podkreślała, że podstawową funkcją dignitas było strzeżenie godności i czci związanej z funkcją lub statusem społecznym tych jednostek, którym dignitas przysługiwało. Współczesna koncepcja godności też ma za zadanie strzec cześć i godność - człowieczeństwa jako nadanego statusu.

Wobec powyższych twierdzeń Hennette-Vauchez nasuwa się kilka wątpliwości. Po pierwsze, czy francuska myślicielka ma rację, opierając się jedynie na kilku wybranych przykładach? A zatem czy rzeczywiście jest tak, że zasada godności człowieka (HDP) strzeże w sposób absolutny godność i cześć człowieczeństwa jako nadanego statusu? Czy wspominane przez nią orzeczenia nie są - mimo że bardzo głośne i kontrowersyjne - jedynie wyjątkowymi i odmiennymi od głównego trendu kulturowego? Czy prawo nie jest dziś raczej na wskroś indywidualistyczne i godność człowieka (wbrew jego woli) chroni w bardzo ograniczonym zakresie. Aby to stwierdzić trzeba by wzorem Hennette-Vauchez oprzeć się na odpowiednich orzeczeniach sądowych i przykładach ze sfery publicznej albo wskazać definicje człowieczeństwa, 
które zawężają jego istotę, kładąc nacisk na różnie pojmowany skrajny indywidualizm. Być może wspominane orzeczenia są raczej łabędzim śpiewem godności człowieczeństwa. Etyka i moralność oraz ich popularne odbicie, czyli kultura masowa (a za nią prędzej czy później także i prawo), idzie raczej w odwrotnym kierunku, czego przykładem są choćby coraz dziwniejsze (często wręcz odzierające z prywatności i godności) programy telewizyjne typu reality show. Koncepcja Hennette-Vauchez jest ciekawa intelektualnie, a proponowane przez nią rozróżnienia sporo wnoszą do doktryny godności. Jednak jej wnioski i hipotezy dotyczące dzisiejszej idei godności wydają się mocno mijać z rzeczywistością społeczną, która przecież znajduje swój bezpośredni wyraz w prawie, a zwłaszcza w orzecznictwie.

Hennette-Vauchez odwoływała się nie tylko do doświadczeń starożytnych, ale i do okresu średniowiecza. Wskazuje na pewne cechy średniowiecznej koncepcji godności. Po pierwsze, podkreśla połączenie indywidualności jednostki z całym ludzkim rodzajem. Hennette-Vauchez wskazała, że zasada godności ludzkiej jest równocześnie indywidualistyczna i uniwersalistyczna. W ten sposób osiągamy jedność ludzkości, która może być zraniona przez zranienie jednostki ${ }^{128}$. Po drugie, godność równocześnie należy do sfery prywatnej i publicznej. Po trzecie dignitas nigdy nie umiera ${ }^{129}$.

Następnie Hennette-Vauchez zajęła się kwestią identyczności funkcji, struktury i reżimu obu porównywanych koncepcji. Według francuskiej profesor dotychczasowa nauka prawa nie dostarczyła - mimo wielu prób - satysfakcjonującej aksjologicznie oraz użytecznej instrumentalnie definicji idei godności. Dlatego lepiej skupić się na tym, czym godność człowieka jest, a nie co oznacza. W pierwszej kolejności jest podstawą obowiązków prawnych albo podstawą zakazów prawnych. Jako dowód wskazuje sprawę z karłami, zakaz dobrowolnej prostytucji ${ }^{130}$, czy zakaz odmowy transfuzji krwi ${ }^{131}$. Przywołuje opinię L.-E. Pettitiego, który zauważył, iż „godność jest bliżej obowiązków niż praw a wykorzystywanie praw niekoniecznie wiąże się z godnością"132. Hennette-Vauchez zauważyła, że każda jednostka jest depozytariuszem części człowieczeństwa, ale nie jest jej właścicielem. Z tego powodu dla jednostek mogą wynikać obowiązki, które ciążą na niej zawsze i wszędzie. Na mar-

${ }^{128}$ Wątpliwa jednak wydaje się teza o jedności ludzkości, głównie z powodu tak licznych odmienności kulturowych, które pociągają za sobą odmienne systemy moralne (np. kwestia honoru i obrazy uczuć religijnych w kulturze Zachodu i islamu).

129 Ibidem, s. 13.

${ }^{130}$ Trzeba jednak przypomnieć, iż w wielu krajach prostytucja jest zalegalizowana albo karane jest tylko sutenerstwo lub stręczycielstwo.

${ }^{131}$ Warto się jednak zastanowić, czy w tym przypadku nie chodzi po prostu o absolutną dominację wartości życia, a nie skutki godności człowieka? Czy podobnie rzecz ma się z zakazem kary śmierci?

${ }^{132}$ Ibidem, s. 14. Wydaje się jednak, że najczęściej wykorzystywanie praw - zwłaszcza podmiotowych - wiąże się z sposób bezpośredni z godnością. 
ginesie warto zauważyć, iż Hennette-Vauchez na uzasadnienie swojej tezy przedstawiła głównie cytaty jurystów francuskich, być może zatem tendencja, na którą wskazuje w swojej hipotezie, występuje najmocniej we Francji. Obowiązki, na które zwraca uwagę, to obowiązki wobec państwa, wobec osób trzecich i wreszcie wobec siebie samego. Hennette-Vauchez przywołuje bardzo interesujący cytat Fabre-Magnona, iż „w czasach inflacji uprawnień i dyskwalifikacji obowiązków, zasada godności pozwala znaleźć rozwiązanie, które uwolni nas od ślepej uliczki, gdzie koncepcja prawa oznacza wyłącznie uprawnienia i przywróci obciążenia i obowiązki w języku praw podstawowych" ${ }^{133}$. Nasuwają się jednak wątpliwości, czy ten cytat nie przeczy tezie Hennette-Vauchez.

Hennette-Vauchez uznała, iż posiadacz godności mógł być zdegradowany, potępiony, a nawet wykluczony (wydalony), jeśli popełnił przewinienie wobec swej godności. Czy jednak tak krytykowana przez nią koncepcja godności (HDP) końca XX w. daje takie możliwości? Wydaje się, że wprost przeciwnie. Żadne czyny człowieka nie uzasadniają traktowania go w sposób nieludzki. Współczesna nam godność jest niezbywalna. Seryjny morderca, bestialski gwałciciel czy pedofil nie tracą swej godności (nie podlegają karze śmierci, a orzekana kara musi spełniać wiele rygorystycznych warunków, m.in. nie może być poniżająca) ${ }^{134}$. Jakikolwiek odrażający moralnie czyn byśmy popełnili, nadal mamy prawo żądać godnego traktowania i nie grozi nam kara, która urągałaby naszej czci, godności czy - szerzej - człowieczeństwu. Nie ma też mowy o zmniejszeniu poziomu ochrony naszej godności, ponieważ godność człowieka jest niepodzielna.

Następnie Hennette-Vauchez przywołała argument odnoszący się do godności obywatelskiej i godności zawodowej. Opisuje bowiem procedurę pozbawienia godności obywatela, jaka obowiązywała w czasie rewolucji francuskiej, która to miała zapoczątkować koncepcję HDP. Czy jednak francuska profesor w ten sposób nie wybiera pewnych elementów, które stanowią dowód jej hipotezy, natomiast wszystkie pozostałe elementy koncepcji godności opatruje krytykowanym przez siebie emblematem koncepcji statutory conception of dignity. Hennette-Vauchez odrzuca niejako ten zarzut, pisząc, iż cywilna degradacja jako kara ukierunkowana była na statutory dignity, a nie na godność człowieka. Następnie przywołała przykład przestępstwa zdrady i kolaboracji z nazistami z 1944 r. (crime of national indignity). Odrzuciła też fakt, iż obecnie utrata obywatelstwa nie może nastąpić z żadnych obiektywnych

\footnotetext{
${ }^{133}$ Ibidem.

${ }^{134}$ Casus Breivika jest w tym kontekście uderzający - wielokrotny morderca w sposób maksymalny wykorzystuje swe prawa wynikające z godności człowieka i skarży się na - jego zdaniem - niehumanitarne warunki: IAR, kk, Breivik się skarży: zimna kawa, za mało masła, dostęp 01.06.2014, http://www.polskieradio.pl/5/3/Artykul/721252,Breivik-sie-skarzy-zimna-kawa-za-malo-masla.
} 
przyczyn (np. w drodze wyroku), ale być wyłącznie następstwem dobrowolnego zrzeczenia się. Hennette-Vauchez skupiła się natomiast na francuskiej procedurze nabycia obywatelstwa ${ }^{135}$ (podobnie, wyłącznie na doświadczeniach francuskich oparty jest argument o godności zawodowej).

W dalszej kolejności Hennette-Vauchez zajęła się kwestią podobnej natury, skupiając się na obowiązkach wobec samej godności. Hennette-Vauchez pisała, iż ,jest jakaś szczególna magia w koncepcji godności, która umożliwia uzasadnienia obowiązków nie tylko wobec osób trzecich, ale i wobec siebie" ${ }^{136}$. W tym kontekście poruszyła kazus zniewagi funkcjonariusza publicznego oraz przywołała jako przykład procesy w sprawie F. Mitterranda i C. Erignaca (zdjęcia naruszały godność urzędu albo godność osobistą). Wydaje się, że w sposób nie do końca przekonujący Hennette-Vauchez obarczyła krytycznymi uwagami godność urzędu w oderwaniu od godności osobistej. Przywoływane kazusy mogłyby być przecież rozstrzygnięte inaczej.

Następnie Hennette-Vauchez zajęła się także problemem podobieństwa obu koncepcji w kontekście niezbywalności ${ }^{137}$. Ale od razu należy poczynić krytyczną uwagę, wskazując iż Hennette-Vauchez wcześniej pisała o degradacji i pozbawieniu praw obywatelskich, a więc o zbywalności godności, jako efekcie właśnie koncepcji dignitas. Jest tu więc pewna nieścisłość. Hennette-Vauchez uważa, iż w kontekście reżimu godności należy odróżnić dwie sytuacje: pierwszą, w której człowiek postępuje przeciwko swoim prawom, i drugą, w której jednostka zrzeka się swych praw. Według Hennette-Vauchez godność - tak jak niektóre prawa człowieka - musi być zbywalna i musi być możliwość zrzeczenia się jej.

Przyznać trzeba, iż wobec powyższych twierdzeń Hennette-Vauchez rodzi się zasadnicza wątpliwość. Czy powojenna koncepcja godności w jakikolwiek sposób różniła się w tym miejscu od dwóch tak krytycznie omawianych koncepcji? Czyż bowiem tamta koncepcja przewidywała możliwość zrzeczenia się godności? Absolutnie nie. Ponownie więc argumentacja Hennette-Vauchez może być uznana za jednostronną. Zamiast jako cechę przynależną wszystkim koncepcjom godności, Hennette-Vauchez krytycznie opisuje ją jako cechę charakterystyczną dla dwóch z nich. Co więcej, mimo że tak chętnie, pisząc o idei dignitas, powołuje się na przykłady średniowieczne, zapomina, że w wyjątkowych sytuacjach można było cześć i godność utracić - istniały bowiem kary na czci, skutkujące pozbawieniem praw i wyjęciem spod prawa (taka osoba mogła być zabita przez każdego bez żadnych konsekwencji), banicja, wygnanie, śmierć cywilna, czyli utrata pewnych praw - dziś powiedzielibyśmy podmiotowych - osób wysoko urodzonych. Co najważniejsze, Hennette-Vauchez pominęła w swych rozważaniach skutki ekskomuniki. Czymże

\footnotetext{
${ }^{135}$ Warto zaznaczyć, iż w polskim prawie nabycie obywatelstwa wygląda odmiennie.

${ }^{136}$ Ibidem, s. 17.

${ }^{137}$ Ibidem, s. 19.
} 
bowiem innym niż pozbawieniem godności królewskiej było wyklęcie władcy i wyłączenie go ze wspólnoty chrześcijańskiej? Jak silna była to broń, wiedział jeden z cesarzy niemieckich, który pod murami Canossy w worze pokutnym musiał błagać papieża o zdjęcie klątwy. Nie można zatem zgodzić się ze stwierdzeniem Hennette-Vauchez, iż rzeczywiście nie ma żadnych wątpliwości, iż dignitas jest niezbywalna ${ }^{138}$.

Hennette-Vauchez wskazała, iż starożytna dignitas i współczesna zasada godności człowieka jest połączona z funkcją (urząd, urodzenie), a nie z osobą. Podobnie współczesna zasada godności człowieka jest połączona z funkcją (człowieczeństwo), a nie z osobą (jednostką). Czy jednak ta technicznokoncepcyjna konstrukcja (technical - conceptual construction) w odniesieniu do człowieczeństwa nie jest czymś zupełnie odmiennym? Czy wręcz instynktownie nie zgadzamy się z traktowaniem człowieczeństwa jako funkcji? Faktem jest, że godność uważana jest za niezbywalną - zarówno w końcu XX w., jak i bezpośrednio po wojnie - właśnie dlatego, że w czasie ludobójstwa dokonanego przez III Rzeszę pozbawiono miliony ludzi tej istotnej części ich jestestwa - człowieczeństwa.

Być może w tym miejscu Hennette-Vauchez miała rację, wskazując na odmienności między koncepcjami godności. Okrucieństwo systemów totalitarnych (nie tylko nazistowskich, na które wskazuje Hennette-Vauchez) spowodowało powstanie Organizacji Narodów Zjednoczonych i systemu międzynarodowej ochrony praw człowieka, gdzie expressis verbis przyznaje się, że skala zbrodni przekroczyła pewien punkt krytyczny. Czy jednak dziś nie mamy do czynienia z procesem o dużo bardziej subtelnym przebiegu niż totalitarne barbarzyństwo - gdy coraz więcej czynów, zdarzeń i zjawisk jest niezgodnych z naszym intuicyjnym pojmowaniem zachowania godnego miana człowieka?

Podsumowując, Hennette-Vauchez uznała, iż zasada godności ludzkiej końca XX w. jest błędnie określana jako pochodząca od powojennej koncepcji godności, ponieważ jest ona jedynie powtórzeniem starożytnej koncepcji dignitas, które w swej istocie jest statusem, a nie humanistyczną ideą. Na potwierdzenie tej tezy Hennette-Vauchez podała przykłady orzeczeń sądowych, m.in. zakaz rzucania karłami, który według niej narusza godność pracującego tam człowieka - skoro bowiem karzeł godzi się, by nim rzucano, to nie powinno być problemu.

Na koniec Hennette-Vauchez wskazała na trzy wątpliwości. Po pierwsze, czy jest możliwe zapewnienie, iż zasada godności ludzkiej pozytywnie i na zawsze pozbyła się swej wrodzonej przypadkowości i kruchości (jej warunkowości)? Czy to jednak nie był też problem powojennej koncepcji godności człowieka? Po drugie, jak możliwe jest budowanie koncepcji godności jako

${ }^{138}$ Ibidem, s. 21. 
statusu i zagwarantowanie, że nikt nie będzie go pozbawiony? Po trzecie, jeśli godność odnosi się do obowiązków moralnych (moral duties) i obowiązków prawnych (legal obligations), to co z tymi, którzy odmawiają ich przestrzegania? I wreszcie, co z obietnicą z 1948 r., wyrażoną w Powszechnej deklaracji praw człowieka - czy można ją uznać za spełnioną, gdy proces demokratyzacji kończy się zastosowaniem instytucji ancien regime, czyli nakazu ciążącego na ludziach ${ }^{139}$.

\author{
FROM THE DIGNITY OF THE WELL-BORN \\ TO THE EGALITARIAN NOBILITY TO ALL. \\ AN OUTLINE OF A STUDY ON HUMAN DIGNITY
}

\title{
Summary
}

The idea of human dignity belongs to the foundations of the $20^{\text {th }}$ century liberal democracy. Being an indispensible element of the human rights system, it also plays an important role in democratic legal systems. This paper aims to present some exceptions to the rule, that have evolved in the last two hundred years of the newest history of the concept and idea of dignity. First, the views of Edmund Burke, the founder of modern conservatism, contained in his Reflections of the Revolution in France, are presented as an example of a conservative voice in the face of revolution and the birth of the idea of human rights. Against those opinions and views expressed by Mary Wollstonecraft, an advocate for women's rights, a feminist philosopher and a representative of Anglo-Saxon liberalism are also presented. This is followed by presentation of views of Gregory Vlastos who, in the 1980s, proposed an original conception of dignity as an egalitarian idea with an egalitarian content. His idea was further developed by an Anglo-Saxon philosopher and law theorist Jeremy Waldron. The paper ends with some critical remarks and opinions of a French professor Stephanie Hennete-Vauchez.

DE LA DIGNITÉ DES BIEN NÉS À LA NOBLESSE ÉGALITAIRE POUR TOUS. L’ESQUISSE DES ÉTUDES CONSACRÉES À LA NOTION DE LA DIGNITÉ HUMAINE

\section{Résumé}

La notion de la dignité humaine est l'un des fondements de la démocratie libérale au vingtième siècle. Cet élément indispensable du système des droits de l'homme

${ }^{139}$ Ibidem, s. 24. 
joue un rôle important dans les systèmes juridiques des pays démocratiques. L'article vise à décrire toutes les exceptions rélevées dans la plus récente histoire que connaît l'idée de la dignité, remontant à il y a plus de deux siècles. Tout d'abord, seront présentées les opinions du père du conservatisme, Edmund Burke, que l'on retrouve dans ses Réflexions sur la Révolution de France. Ses idées constituent l'exemple d'un immobilisme face à la révolution et de la naissance de la notion des droits de l'homme. Par contre, les opinions et idées de Mary Wollstonecraft, considérée comme l'un des précurseurs du mouvement des suffragettes, de la philosophie féministe et du libéralisme anglo-saxon constituront une voix contre la réalité constatée (voix de polémique par rapport en tout cas à l'opinion de Burke). Ensuite, interviendra la description des idées de Gregory Vlastos qui, dans les années 80 du $\mathrm{XX}^{\mathrm{e}}$ siècle a élaboré une conception originale de la dignité considérée comme idée égalitaire au contenu d'élite. Ce concept sera par ailleurs développé par Jeremy Waldron, philosophe anglo-saxon et théoricien du droit. À la fin, nous présenterons quelques critiques du concept, ces remarques ayant été faites par le professeur français, Mme Stéphanie Hennette-Vauchez. 